\title{
Experiences with the Introduction of a Payment Moratorium in Hungary*
}

\author{
Áron Drabancz - Gabriella Grosz - Alexandr Palicz - Balázs Varga
}

The payment moratorium, which was introduced in the wake of the coronavirus pandemic in Hungary as well, has become an internationally widespread crisis management tool. In our study, we analyse the demographic and income characteristics of bank clients who have participated in the payment moratorium and the direct impact of the payment moratorium on the liquidity of debtors and on bank profitability. The analysis is based on transaction-level data available to the Magyar Nemzeti Bank (the Central Bank of Hungary, MNB) that is detailed in international comparison as well. Based on our examination, the payment moratorium has proven to be an effective tool for mitigating the short-term default risk of potentially vulnerable debtors. It has also provided significant additional liquidity at the level of the national economy to offset the negative impacts of the pandemic, while causing only moderate direct costs at the level of the banking system. On the whole, the payment moratorium can be considered an effective and efficient crisis management tool for exogenous economic shocks similar to the coronavirus pandemic, which is also confirmed by its international prevalence.

Journal of Economic Literature (JEL) codes: E32, E58, G21, G28, G32, G33, G38, M48 Keywords: coronavirus pandemic, financial stability, payment moratorium, credit risk, financial regulation

\section{Introduction}

The coronavirus pandemic has caused a serious, protracted financial and economic crisis around the world. During the first wave, closures broke the continuity of supply chains (Figure 1), causing significant disruptions in the real economy. The deteriorating macroeconomic environment affects the financial sector primarily through mounting credit losses and the rise in liquidity and funding risks (EBA 2020a; FSB 2020). At the same time though, with health hazards and digitalisation

* The papers in this issue contain the views of the authors which are not necessarily the same as the official views of the Magyar Nemzeti Bank.

Áron Drabancz is a Junior Analyst at the Magyar Nemzeti Bank.Email: drabancza@mnb.hu Gabriella Grosz is an Economic Analyst at the Magyar Nemzeti Bank. Email: groszg@mnb.hu Alexandr Palicz is an Economic Analyst at the Magyar Nemzeti Bank. Email: palicza@mnb.hu Balázs Varga is an Analyst at the Magyar Nemzeti Bank. Email: vargaba@mnb.hu

The Hungarian manuscript was received on 15 December 2020.

DOI: http://doi.org/10.33893/FER.20.1.542 
coming to the fore, operational risks and cyber defence (BIS 2021) are becoming more relevant.

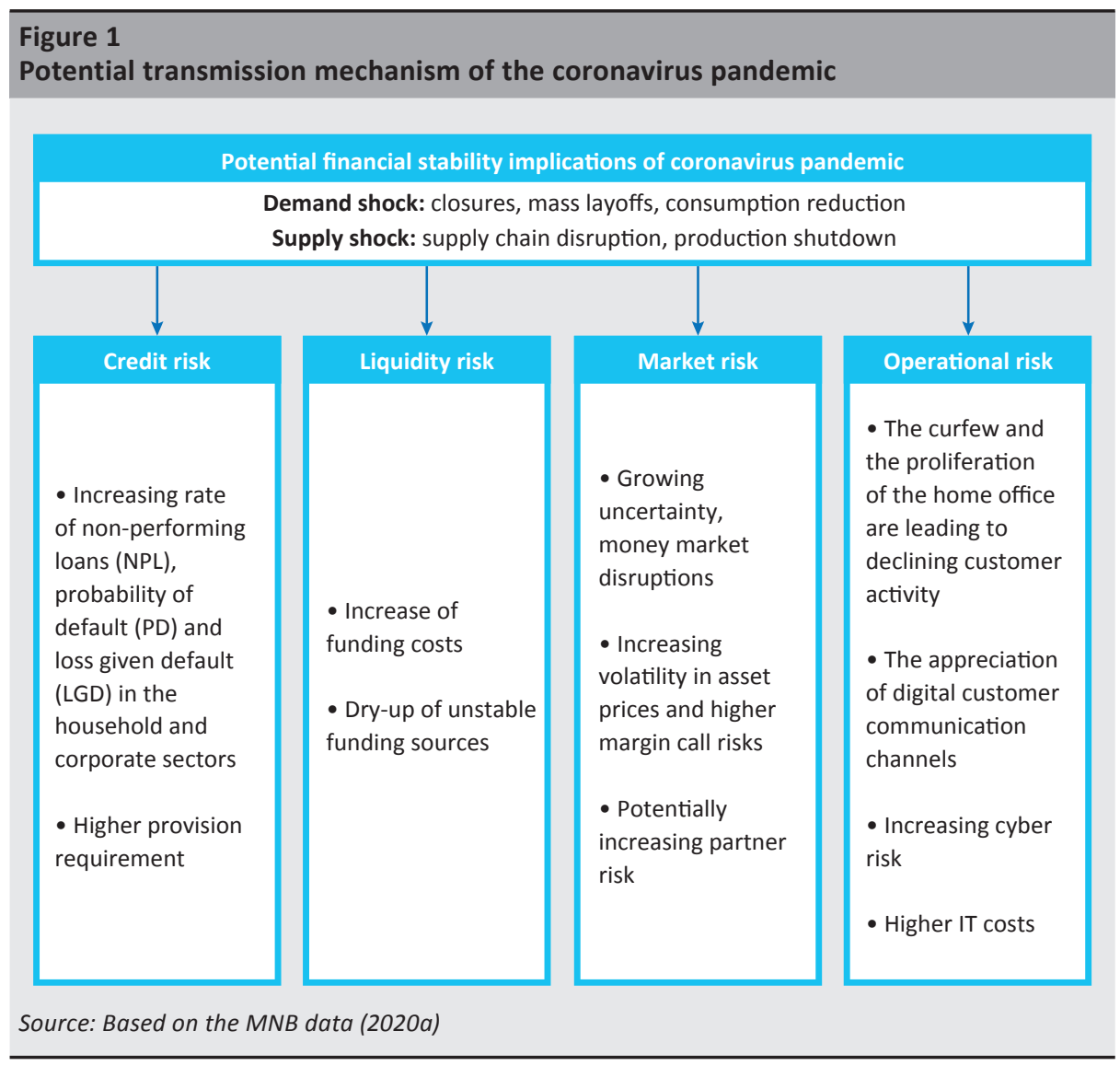

The short-term global financial stability risks posed by the coronavirus pandemic may be mitigated by crisis management interventions of unprecedented size. Until the launch of coronavirus vaccinations, economic recovery depends on prolonging the supportive measures of the governments and the central banks (BIS 2020a; IMF 2021). Within the framework of these measures, decision-makers tried to mitigate negative impacts with the help of fiscal, monetary, micro- and macroprudential tools as well. Governments worldwide provided support worth around USD 12 trillion to households and businesses (IMF 2020) via fiscal policy measures. In terms of monetary policy, as a result of the pandemic, the central banks of the G10 countries increased their balance sheets by around USD 7.5 trillion, and about 20 developing economies have introduced an asset purchase programme for the first time ever. Microprudential supervisory interventions include the temporary 
suspension of capital and liquidity regulations and the temporary authorisation of limit violations, which played a role in the increase of financial institutions' lending capacity. The macroprudential framework which has been created in the recent years has successfully stood its first crisis test since the global banking system faced the economic shock of the coronavirus pandemic with high capital and liquidity reserves and adequate resilience (Terták - Kovács 2020).

The economic policy responses to the economic challenges posed by the pandemic primarily support the financial system in two ways. First of all, they strengthen the lending capacity of the financial institutions since this is the best way that they can mitigate real economic recession. Second, they enhance the stability of the financial system which may be endangered primarily by the rising credit loss. Decision-makers basically maintained banks' lending capacity by easing capital requirements and increasing liquidity. In addition, fiscal policy measures, state and central bank credit and guarantee schemes and payment moratoria provide significant help in bridging temporary liquidity shortages, thus protecting supply chains and maintaining the functioning of the economy. Furthermore, payment moratoria counterbalance potential short-term credit losses stemming from the deteriorating payment ability of distressed debtors. However, proactive bank restructurings and the regulatory incentive for bank balance sheet clean-up can help the most in maintaining portfolio quality in the long term (BIS 2020b).

In our study, in relation to the coronavirus pandemic, payment moratoria are discussed, as the most widespread instrument applied for the mitigation of shortterm credit losses, with a focus on Hungary's approach. We discuss the transmission mechanism of the payment moratorium in the second section, while in the third section, we also analyse the international experiences with the use of this measure. In part four we examine the impacts of the domestic payment moratorium on the households and businesses participating in the programme, based on internationally outstanding, uniquely detailed data available to the MNB. In doing so, we also address the impact of the payment moratorium on liquidity and on banking profitability, and we argue that this measure has effectively mitigated households' liquidity shortage, while it has caused only limited and manageable losses for the banks. In section five, the expected impacts of the extension of the payment moratorium until June 2021 are presented. Finally, in light of the favourable impacts and potential costs of the moratorium, the study concludes that the measure has proved to be an effective crisis management tool in total. 


\section{The transmission mechanism of the payment moratorium}

The basic purpose of the payment moratorium is to aid debtors who are struggling with temporary liquidity shortages, but who are solvent over the longer term, thus avoiding a drastic increase in the non-performing loan portfolio and maintaining economic activity (Figure 2). A payment moratorium counterbalances the income loss of households and companies resulting from the coronavirus pandemic via the temporary suspension of payment obligations. The moratorium prevents or delays potential non-performance, thus mitigating the immediate impact of the pandemic and providing time for the necessary adaptation by market actors. By maintaining banks' portfolio quality, the moratorium reduces the extent of and provides more time for the potentially necessary loan loss provisioning. By mitigating and prolonging the risks posed by the pandemic, the moratorium also reduces banks' potential capital losses.

The payment moratorium decreases the liquidity inflow of the banks from loan repayment, but liquidity risks do not emerge at the banking system level. This is because delayed instalments ultimately appear on the liability side of the banks at the systemic level, via the increased savings or consumption of the debtors, as if debtors had completed their repayment obligation. However, the liquidity effect among banks may be uneven, which may require additional liquidity for institutions possibly encountering a more difficult situation, which is supported by the MNB with monetary policy instruments (MNB 2020b).

In the international literature and professional community, the assessment of the impact of the payment moratorium is not clear: in earlier cases, banks drew attention to the default risk stemming from increasing moral hazard, while supporters pointed out the increased amount of time that borrowers could spend on gathering information and accumulating liquidity because of the moratorium. Furthermore, supporters also highlight that a properly introduced moratorium may even improve non-performing debtors' willingness to pay in the long run, due to increased trust in the system (Collins - Urban 2018). 


\section{Figure 2}

Transmission mechanism of the payment moratorium

\begin{tabular}{|c|c|c|}
\hline $\begin{array}{c}\text { Payment } \\
\text { moratorium }\end{array}$ & $\begin{array}{c}\text { Banking system } \\
\text { effects }\end{array}$ & $\begin{array}{c}\text { Real economic } \\
\text { effects }\end{array}$ \\
\hline ㄹㄹㄹ & $\begin{array}{l}\text { Asset quality: } \\
\checkmark \text { Debtors' default risk } \\
\text { decreases in the short term } \\
\text { as their liquidity difficulties } \\
\text { decrease } \\
\checkmark \text { Growth in non-performing } \\
\text { loans may remain modest } \\
x \text { Due to moral hazard, } \\
\text { long-term default may } \\
\text { increase } \\
\text { Liquidity: } \\
- \text { Liquidity risk does not } \\
\text { arise on banking sector level } \\
\text { Profitability: } \\
\checkmark \text { Lower provisioning } \\
\text { requirement due to } \\
\text { increased credit risk } \\
\text { of debtors } \\
x \text { Change in the present } \\
\text { value of loans may result } \\
\text { in direct loss } \\
\text { Business environment: } \\
\checkmark \text { Higher credit demand and } \\
\text { faster recovery due to the } \\
\text { economic stimulus effect } \\
\text { of the moratorium (smaller } \\
\text { downturn and unemployment) }\end{array}$ & $\begin{array}{l}\text { Households: } \\
\checkmark \text { Lesser liquidity difficulties, } \\
\text { milder consumption decline, } \\
\text { greater shock resistance } \\
\text { Corporates: } \\
\checkmark \text { Lesser liquidity difficulties, } \\
\text { smaller decline in } \\
\text { employment, greater } \\
\text { resilience to shocks } \\
\text { Government: } \\
\checkmark \text { Slight decrease in economic } \\
\text { activity, a smaller decrease } \\
\text { in tax revenues } \\
\checkmark \text { Smaller increase in } \\
\text { required social transfers }\end{array}$ \\
\hline
\end{tabular}

The impact of granting a deferral on bank impairment and profit is regulated by international accounting standard IFRS 9. According to IFRS 9, lenders must recognise an impairment corresponding to the expected annual loss on transactions related to lenders' performing exposures. If the transactional credit risk increases significantly, exposures must be classified into the so-called Stage 2 (financial instruments with significantly increased credit risk) or Stage 3 (non-performing financial instruments) categories. In Stage 2 or in Stage 3, however, the amount of the impairment should be determined on the basis of the expected loss over the total lifespan. In Stage 3 , the interest income of the transactions should be calculated on the basis of the net book value (BIS 2020c), resulting in a significant negative income impact. If the general regulations on deferral were applied to payment moratorium, it would result in the wholesale classification of the transactions into Stage 2 or Stage 3 and would seriously decrease the result and deteriorate lenders' capital position. 
In order to avoid the broad impairment of credit transactions under a moratorium, the international regulatory authorities issued resolutions on the exceptional accounting treatment of payment moratoria introduced in the wake of the COVID-19 pandemic. The International Accounting Standards Board (IASB), the Basel Committee on Banking Supervision (BCBS), the European Banking Authority $(E B A)^{1}$ and the MNB issued guidelines ${ }^{2}$ and an executive circular ${ }^{3}$ that participation in a payment moratorium introduced in the wake of the coronavirus pandemic does not on its own indicate a significant rise in credit risk, and thus does not result in the necessity to reclassify the exposures as financial exposures with increased risk (Stage 2) according to IFRS 9, nor to classify the exposures as restructured or nonperforming claims. The regulatory authorities argue that entering the moratorium itself is not an event referring to the increased credit risk of clients, but represents participation in a broad governmental programme that mitigates debtors' temporary liquidity shortages. Therefore, according to the authorities, the accounting treatment of the payment moratorium differs from forbearance measures initiated by debtors due to a deterioration in their solvency, and participation in the moratorium on its own does not necessitate loan loss provisioning. Nonetheless, banks already started preparing for the management of potential future losses in 2020 by generating a larger amount of portfolio-level impairment. In Hungary, during the first nine months of 2020 HUF 294 billion of impairment and provision was formed, while in same period of 2019 it was only HUF 30 billion.

The potential profitability impact of the payment moratorium depends on its implementation details and on the change in the present value of loans subject to the moratorium. Although the payment obligation is suspended for debtors participating in the moratorium, payments become due regardless of the moratorium and shall be paid after its expiration according to the implementational details. Since the moratorium does not affect the legal basis of the lenders' claims, lenders do not suffer direct interest loss according to the practices of most countries. Lenders' potential loss stemming from the payment moratorium is the result of the impact of the moratorium on the present value of the loans and therefore it is highly dependent on the specific form of the moratorium. Present value change or direct bank losses do not arise if the interest of unpaid capital is capitalised and compound interest is applied. If the capitalisation of interest is omitted, however, lenders suffer the loss of the present value, which stems from the loss of the potentially recoverable additional interest. The accounting of the decrease in the loans' present value differs from one lender to another. It may appear as provisioning

\footnotetext{
${ }^{1}$ https://eba.europa.eu/eba-provides-clarity-banks-consumers-application-prudential-framework-light-covid19-measures, and https://eba.europa.eu/regulation-and-policy/credit-risk/guidelines-legislative-and-nonlegislative-moratoria-loan-repayments-applied-light-covid-19-crisis

${ }_{2}$ MNB Press release: https://www.mnb.hu/sajtoszoba/sajtokozlemenyek/2020-evi-sajtokozlemenyek/ magyarorszagot-kovette-az-eu-a-fizetesi-moratorium-banki-hatasainak-megiteleseben

${ }^{3}$ MNB Executive Circular: https://www.mnb.hu/letoltes/tmp3dd8-tmp-23297446.pdf
} 
or as impairment as well. The resulting potential loss of the lenders therefore immediately decreases the result when debtors enter the moratorium (Figure 3).
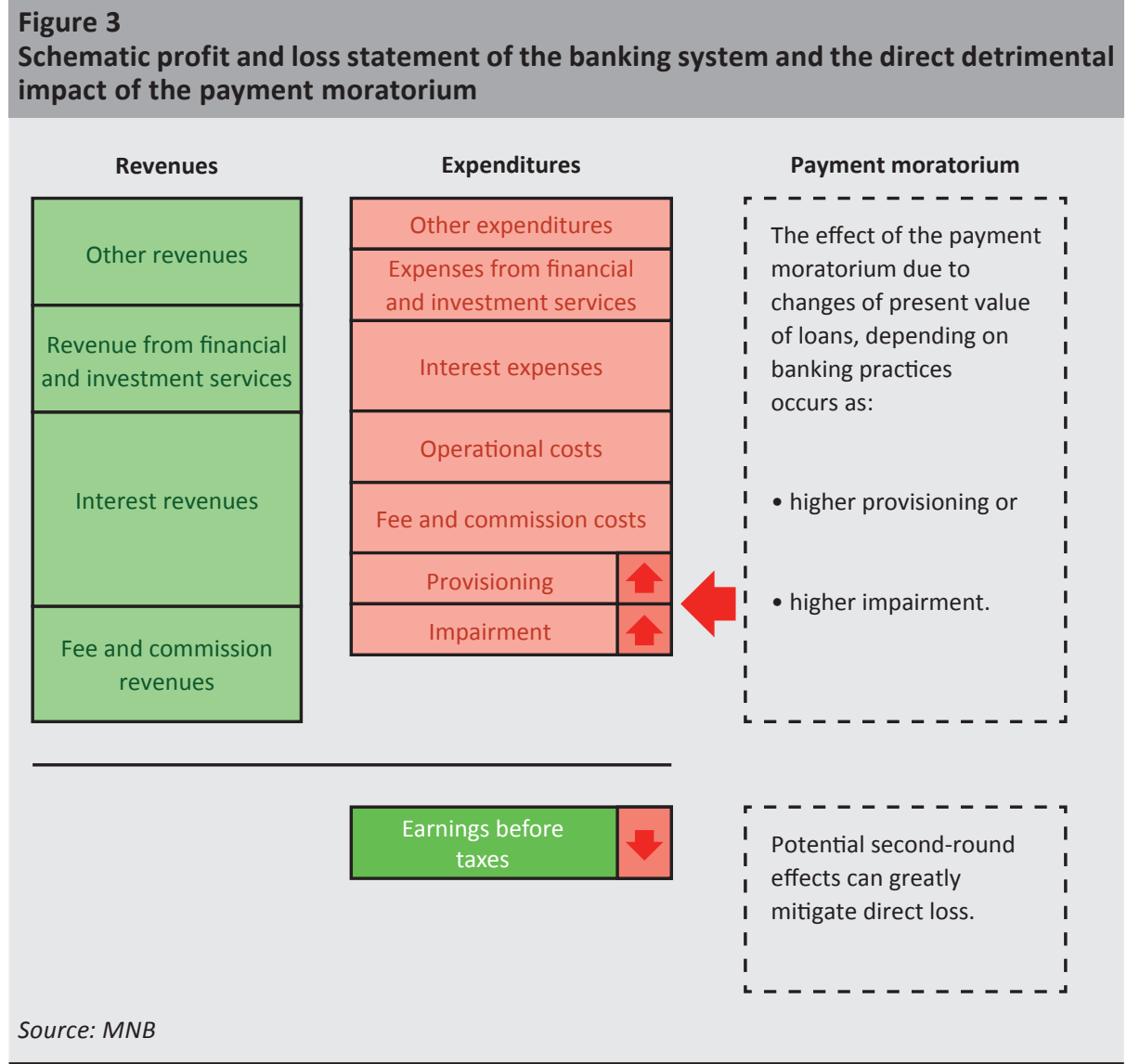

Lenders' potential losses may be largely counterbalanced by the smaller capital loss stemming from the maintenance of portfolio quality and by the smaller decline in demand stemming from the support for the general business environment. By mitigating the liquidity shortfall, payment moratorium may contribute significantly to maintaining the supply chains and economic capacities impacted by the pandemic. The liquidity impact, which is significant even at the macroeconomic level, may substantially improve the factors that determine portfolio quality the most, such as economic growth and employment. 


\section{International practice of payment moratoria}

Payment moratoria of some kind have been introduced almost everywhere, in a total of 23 countries, except for the northern European ones, in the European Union (Figure 4); however, the measures introduced differ in many of their characteristics. A high degree of heterogeneity can be observed in terms of the legal form of introduction, the conditions of eligibility, its subject, the means and timespan of application and the potential prolongation of the measures in light of the pandemic situation.

\section{Figure 4 \\ International practice of payment moratoria in the EEA countries and the United Kingdom (as of 2 February 2021)}

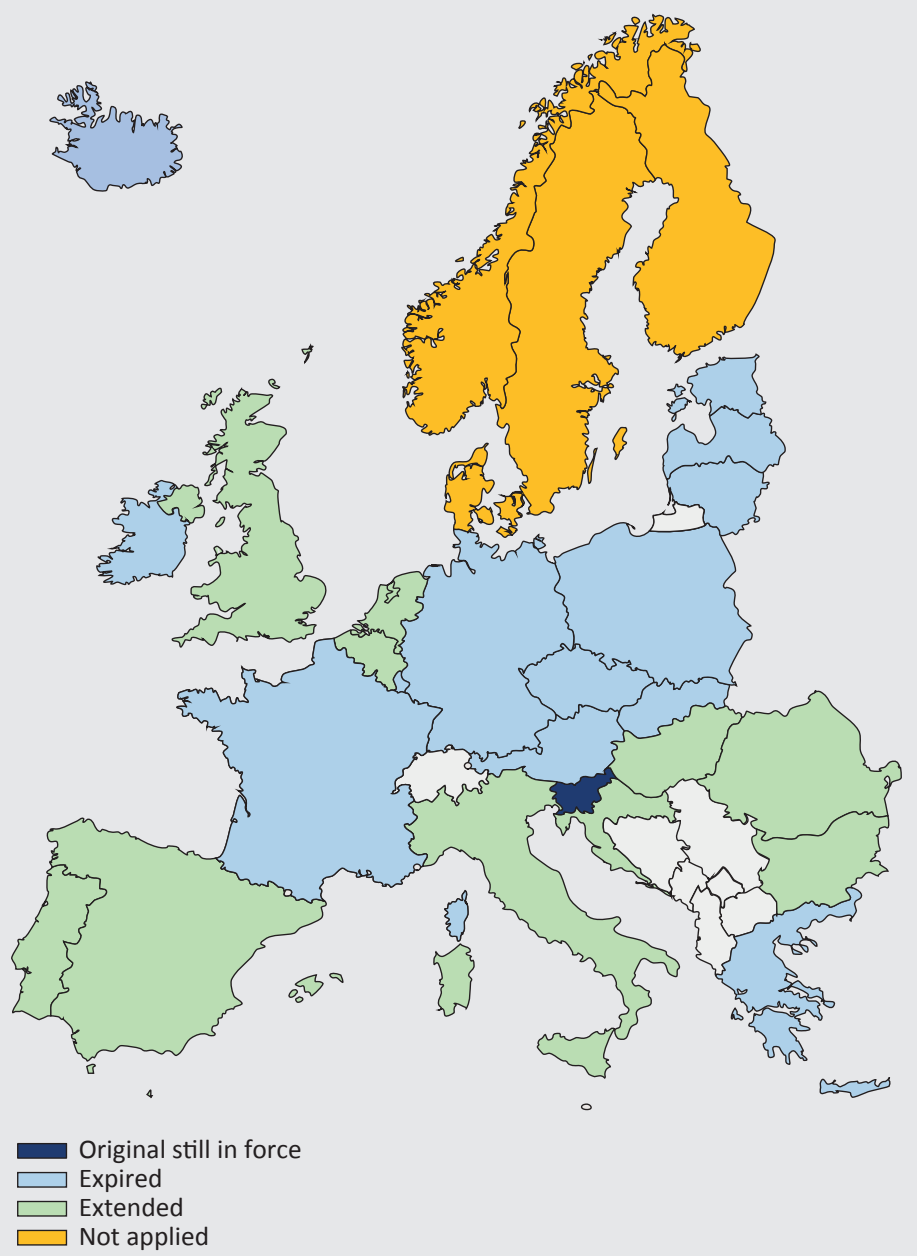

Source: Data retrieved from European Systemic Risk Board (ESRB), MNB 
- Legal form: In the EU, in addition to Hungary, fourteen countries acted within the legal framework, while nine countries developed common practices for a payment moratorium by adopting a banking association recommendation.

- Eligibility: A broad-based, unconditional payment moratorium on corporate and household loan instalments, as in Hungarian practice, was not common in other EU Member States. In the international context, a typical feature of the measures is that moratorium can only be granted if certain conditions are met. Such conditions include, for example, being unemployed, operating or being employed in an industry affected by the pandemic, a drop in income or revenue proven to be the result of the situation, or residing or operating in the economic and geographical areas particularly affected by the pandemic.

- Application: In terms of the entry into the moratorium, Hungary uniquely implemented the opt-out type of mechanism, i.e., the measure was automatically applied for the debtor, and no separate request was needed to be submitted. In the other EU Member States, an opt-in type of measure was implemented, i.e. the debtor could submit a request for the moratorium.

- Subject of the payment moratorium: Similarly to Hungary, in most EU countries, the measure applies to both interest and principal, with the exception of Germany and Spain, where the moratorium only applies to principal.

- Period of the payment moratorium: No payment moratorium was imposed in the Nordic countries at all, while in the case of the other northern countries (United Kingdom, Ireland and Iceland), measures were only introduced for a short period of 3-6 months. Of these, Ireland extended the payment moratorium by 3 months, while in the UK a limited moratorium can be exercised for another 3 months, for a total of 6 months. Apart from these, no payment moratoria are currently in effect in the northern countries. EU countries typically declared a payment moratorium for a period of 3 to 6 months, while Central and Eastern European countries defined a longer, 6- to 9-month period for the payment moratorium. Among the indicators measuring the competitiveness of pandemic control, the period of the payment moratorium announced in Hungary is outstanding in an international context, as Báger - Parragh (2020) also points out.

- Extension: Due to the protracted pandemic, the measures originally introduced have been extended in several countries, such as Austria and Portugal. The extension was granted in countries approaching the original expiry of the payment moratorium or implementing a payment moratorium that had already expired in the meantime. In general, according to international practices to date, the extensions were applied to a more limited range of eligible debtors, such as unemployed debtors with confirmed loss of income or those working in tourism, and they were effective typically until the end of the year or by June 2021. After 
the expiry of the payment moratoria announced at the time of the pandemic outbreak, the payment moratoria of only 11 countries (UK, BG, HR, RO, SI, BE, NL, IT, MT, PT and ES) are still in effect, in addition to Hungary (Table 1).

\begin{tabular}{|c|c|c|c|c|c|c|c|}
\hline \multicolumn{8}{|l|}{$\begin{array}{l}\text { Table } 1 \\
\text { Internatic }\end{array}$} \\
\hline Region & $\begin{array}{l}\text { Country } \\
\text { code }\end{array}$ & $\begin{array}{l}\text { Payment } \\
\text { moratorium } \\
\text { in effect }\end{array}$ & $\begin{array}{l}\text { Opt-in/ } \\
\text { Opt-out }\end{array}$ & $\begin{array}{c}\text { Mandatory } \\
\text { for banks }\end{array}$ & $\begin{array}{l}\text { Scope of } \\
\text { eligibility }\end{array}$ & $\begin{array}{c}\text { Period } \\
\text { of the } \\
\text { moratorium } \\
\text { (month) }\end{array}$ & $\begin{array}{l}\text { Period of } \\
\text { extension } \\
\text { included } \\
\text { (month) }\end{array}$ \\
\hline \multirow{6}{*}{$\begin{array}{l}\text { Northern } \\
\text { countries }\end{array}$} & DK & No & No & No & None & 0 & 0 \\
\hline & $\mathrm{FI}$ & No & No & No & None & 0 & 0 \\
\hline & IE & Expired & Opt-out & No & General & 6 & 3 \\
\hline & SE & No & No & No & None & 0 & 0 \\
\hline & UK & Extended & Opt-in & No & Limited & 6 & 3 \\
\hline & IS & Expired & Opt-in & Yes & Limited & 6 & 0 \\
\hline \multirow{11}{*}{$\begin{array}{l}\text { CEE and } \\
\text { Baltics }\end{array}$} & SK & Expired & Opt-in & Yes & General & 9 & 0 \\
\hline & $\mathrm{EE}$ & Expired & Opt-in & No & Limited & 5 & 0 \\
\hline & LV & Expired & Opt-in & Yes & Limited & 6 & 0 \\
\hline & LT & Expired & Opt-in & No & General & 6 & 0 \\
\hline & $B G$ & Extended & Opt-in & Yes & General & 12 & 6 \\
\hline & HR & Extended & Opt-in & No & General & 15 & 12 \\
\hline & $\mathrm{CZ}$ & Expired & Opt-in & Yes & Limited & 6 & 0 \\
\hline & $\mathrm{HU}$ & Extended & Opt-out & Yes & General & 15 & 6 \\
\hline & $\mathrm{PL}$ & Expired & Opt-in & No & Limited & 6 & 0 \\
\hline & RO & Extended & Opt-in & Yes & General & 12 & 3 \\
\hline & SI & Introduced & Opt-in & Yes & General & 12 & 0 \\
\hline \multirow{6}{*}{$\begin{array}{l}\text { Core } \\
\text { countries } \\
\text { of the } \\
\text { euro area }\end{array}$} & AT & Expired & Opt-in & Yes & Limited & 10 & 7 \\
\hline & $\mathrm{BE}$ & Extended & Opt-in & Yes & Limited & 13 & 3 \\
\hline & $\mathrm{FR}$ & Expired & Opt-in & Yes & General & 4 & 0 \\
\hline & DE & Expired & Opt-in & Yes & Limited & 3 & 0 \\
\hline & LU & Expired & Opt-in & No & Limited & 6 & 0 \\
\hline & $\mathrm{NL}$ & Extended & Opt-in & No & Limited & 15 & 9 \\
\hline \multirow{6}{*}{$\begin{array}{l}\text { Medi- } \\
\text { terranean } \\
\text { countries }\end{array}$} & $\mathrm{CY}$ & Expired & Opt-in & Yes & General & 9 & 0 \\
\hline & GR & Expired & Opt-in & No & General & 9 & 6 \\
\hline & IT & Extended & Opt-in & Yes & Limited & 10 & 4 \\
\hline & MT & Extended & Opt-in & Yes & General & 12 & 6 \\
\hline & PT & Extended & Opt-in & Yes & General & 18 & 12 \\
\hline & ES & Extended & Opt-in & Yes & Limited & 16 & 11 \\
\hline
\end{tabular}




\section{The payment moratorium in Hungary}

\subsection{Data used}

The MNB has detailed, transaction-level data to assess the potential effects of the payment moratorium. Granular data are available from several sources on the debtors participating in the payment moratorium and on the loans and certain demographic characteristics of households and corporate clients. Based on the data sources available, our analysis can provide an accurate overview on the effects of the use of the payment moratorium in Hungary.

The following data sources were used in the analysis of clients entering the payment moratorium and their exposures (Figure 5):

- Central bank credit register: an anonymised database reported by credit institutions on a monthly basis, covering more than 500 attributes of the credit stock and the related borrowers and collateral. However, the current income of borrowers are not included in the credit register, so it does not provide direct information on the current vulnerability of households.

- Data on tax returns and contributions received from the National Tax and Customs Administration of Hungary: anonymised data on the income of natural persons having loans, provided by the tax administration pursuant to the decree of the MNB on reporting obligations. ${ }^{4}$ However, the disadvantage of data based on personal income tax returns is that they are received by the MNB with a considerable delay. Currently, the 2018 data are available from the database of the National Tax and Customs Administration. The client-level data can be linked to the credit register database of the MNB.

- Extraordinary bank reporting: Within the framework of reporting, the banks have provided the MNB, on an anonymised basis, the amount of wages credited to the accounts of bank clients having wages credited in December 2019, broken down by months for the period of January to July 2020. The anonymous client-level data can be linked to the credit register database of the MNB, thus providing an opportunity to carry out a deeper analysis of the income losses resulting from the coronavirus pandemic.

- MNB questionnaire survey: By means of an online questionnaire survey, we obtained information on the financial situation, shock resilience and expectations of bank clients. Nearly 56,000 households and 1,100 corporate debtors completed the survey. In addition to the granular data assets of the MNB, the data retrieved from the questionnaire are a good supplement to the assessment of the employment, savings situation and expectations of clients.

\footnotetext{
${ }^{4}$ Decree No 41/2020. (XI. 18.) of the Governor of the Magyar Nemzeti Bank on the reporting obligations for the central bank information system to be fulfilled primarily in the relation to carry out the basic tasks of the Magyar Nemzeti Bank
} 

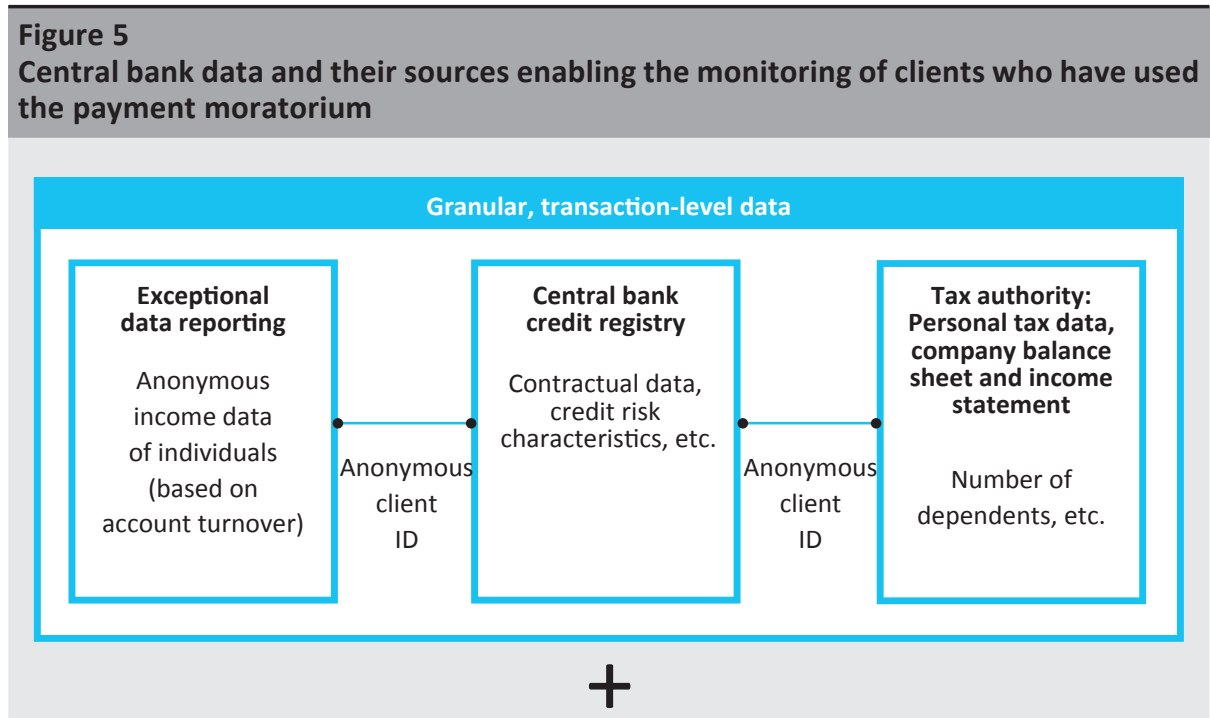

MNB moratorium survey

- Data set: Demographics, employment, income/income, savings characteristics and future expectations

- Household records: 55,891 customers with a loan on 18 March 2020

- Of which 23,147 took the moratorium on at least one of their loans

- Corporate records: 940 customers with a loan on 18 March 2020

- Of which 501 took the moratorium

Source: $M N B$

\subsection{Payment moratorium in Hungary}

In response to the coronavirus pandemic, on 18 March 2020 the Hungarian government announced a payment moratorium on all payment obligations arising from the loans of households, non-financial corporations, financial enterprises and investment funds, effective until 31 December 2020. Based on the payment moratorium, all loan repayments disbursed until 18 March 2020 were automatically suspended until the end of the year without a separate request, but debtors had the right to continue repaying their loans. Clients will not be relieved of the amount of delayed interest accumulated during the moratorium, which shall be repaid after the expiry of the moratorium, annually, in equal instalments over the term of the loan. In accordance with the provisions of the detailed legislation, ${ }^{5}$ the instalment shall not increase after the expiry of the moratorium, and the remaining maturity of the contracts will be extended instead. As delayed interest payments will not be

\footnotetext{
${ }^{5}$ Act LVIII of 2020 on the transitional rules related to the termination of the state of danger and on the epidemiological preparedness. Hungarian Official Journal (Magyar Közlöny), No. 144, 3653-3751.
} 
capitalised during or after the moratorium, debtors can restructure their loans on favourable terms, thus bridging their potential liquidity difficulties.

\subsubsection{Characteristics of retail clients participating in the moratorium and the affected loan portfolio}

According to the first reporting on the use of the moratorium in May 2020, a total of 1.6 million debtors, i.e. about 60 per cent of the 2.7 million bank retail clients ${ }^{6}$ (including debtors and co-debtors) eligible for the moratorium, took part in the payment moratorium for at least one of their loans in the first months of the moratorium period (Figure 6). Recently, the proportion of clients entering the payment moratorium has not changed significantly, and thus their characteristics are presented here based on the latest data for August 2020 available at the time this study was written.

\section{Figure 6 \\ Proportion of retail bank clients entering the payment moratorium among all clients eligible for the moratorium}

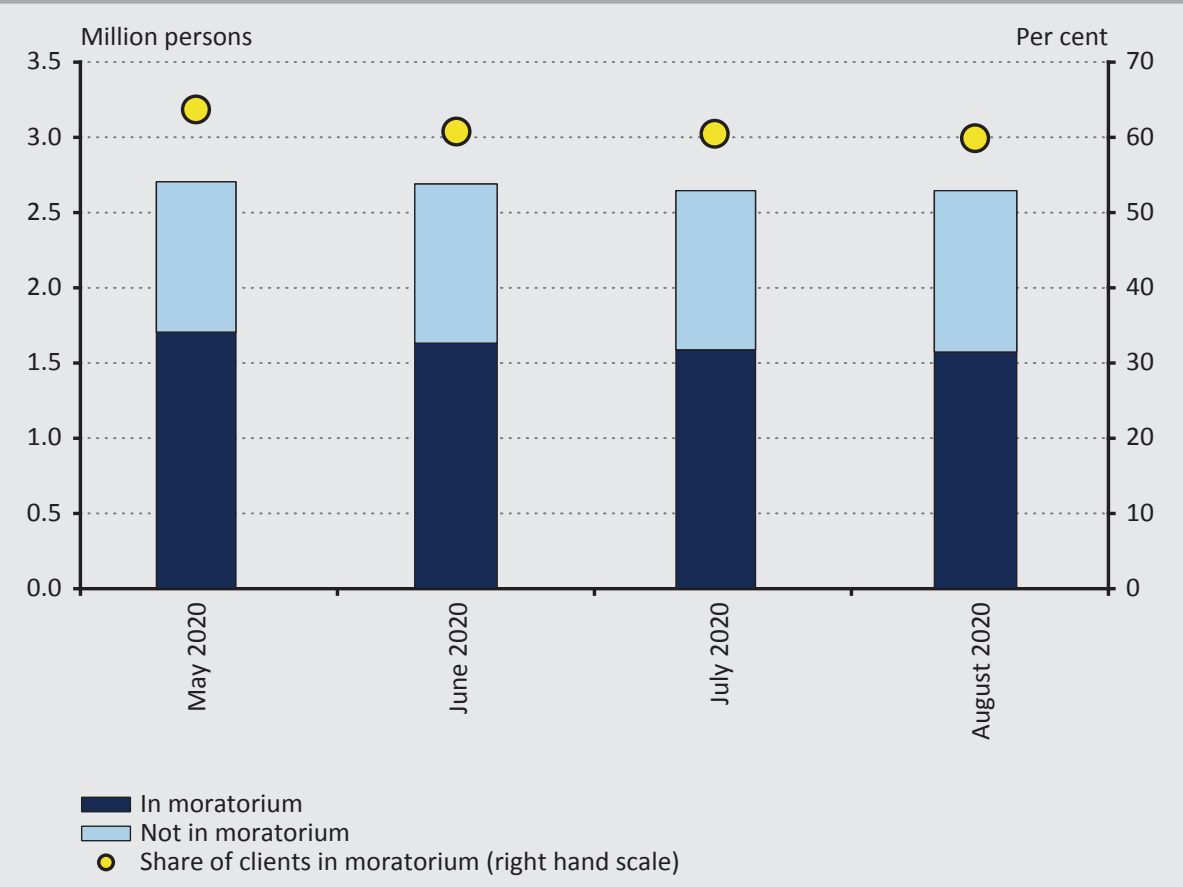

Note: Both debtors and co-debtors participating in the moratorium on at least one of their loans were taken into account as clients entering the moratorium. Only credit institutions sector and natural persons as debtors (excluding sole proprietors and primary producers).

\footnotetext{
${ }^{6}$ In this study, we examined the loan portfolio of the credit institutions sector regarding natural persons as debtors, excluding primary producers and sole proprietors.
} 
According to the latest data of August available at the time this was written, about 1.5 million retail clients in the credit institutions sector entered the moratorium for nearly 1.7 million loan agreements and a loan portfolio amounting to HUF 3,700 billion. By retail customers the moratorium was mostly used for typically higherinterest, shorter-term personal loans. It can be explained by the potentially higher interest rates on consumer loans and the generally low consumer willingness to repay consumer loans. Regarding the use of the moratorium, the proportion of participation in the case of volume-based distributions is similar to the number of contracts (Figure 7), which indicates an even distribution of loans under moratorium.

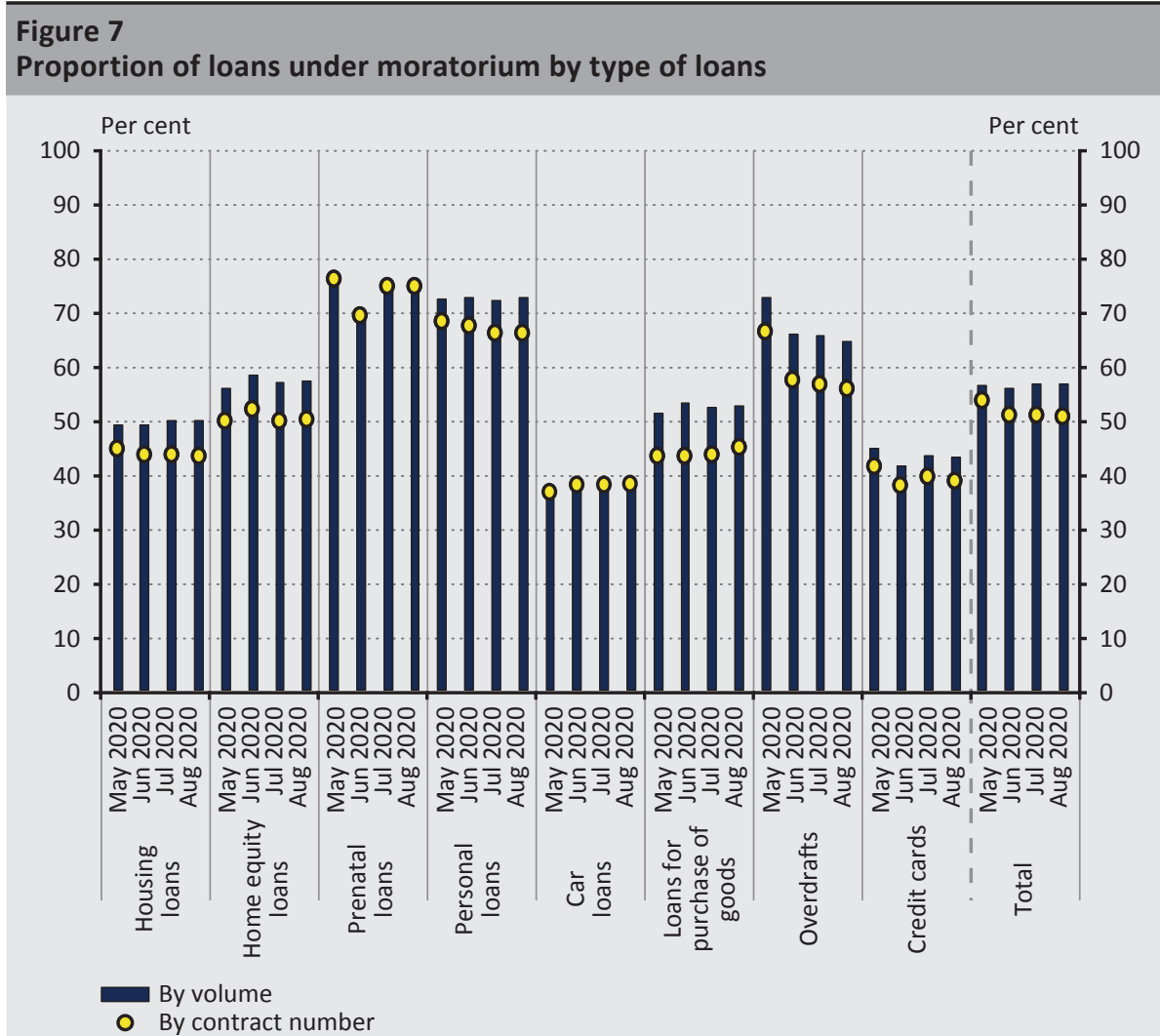

Note: Only credit institutions sector and natural persons as debtors (excluding sole proprietors and primary producers). The proportion of the moratorium on the prenatal baby support loans also includes data on the suspension of repayments related to having children.

Nearly three quarters of the debtors entering the payment moratorium exercised the option for one loan (around 1.1 million persons), one-fifth for two loans (around 300,000 persons), and one-tenth (around 150,000 persons) for three or more loans. Nearly 500,000 people (including debtors and co-debtors), representing one third 
of the clients entering the payment moratorium on at least one of their loans, have a housing or personal loan (or both), and about one fifth had an overdraft facility or a credit card. About 93,000 clients, or 5 per cent of the clients participating in the payment moratorium, had a prenatal loan (Figure 8).

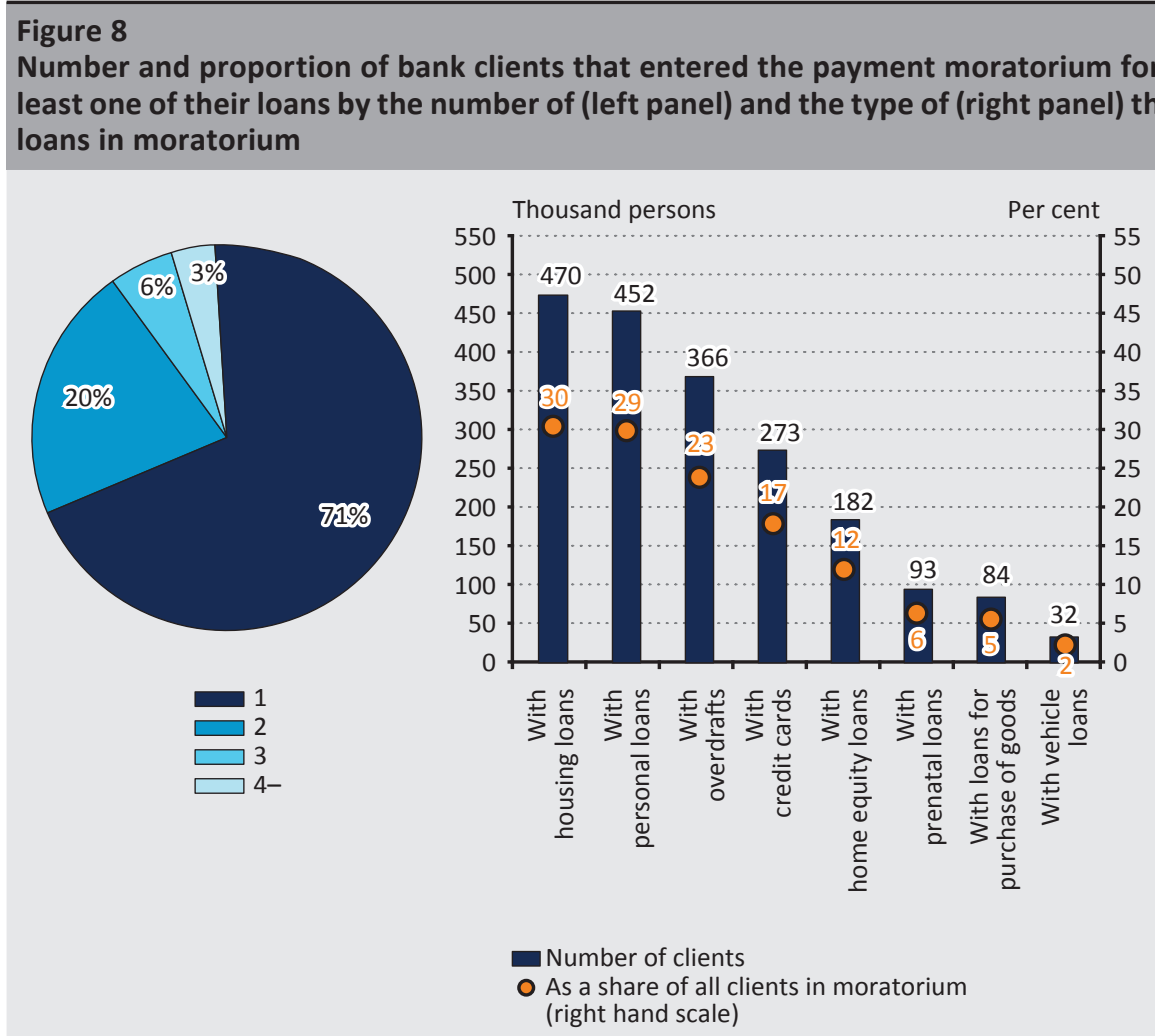

Note: Data for August 2020. Clients participating in the payment moratorium may have more than one loan at the same time, so the data in the right hand chart are not mutually exclusive. Banking sector and natural person debtors only.

Based on the demographic characteristics of clients entering the payment moratorium, it can be concluded that those with reduced shock resilience were more likely to use the programme. The proportion of clients entering the payment moratorium under the age of 35 was 23 per cent, higher by approximately 6 percentage points than clients not in moratorium. The payment moratorium is used by a larger proportion of clients living in smaller municipalities, and in the less developed eastern and southern districts of the country as well, which may be explained by the lower levels of development and employment in these areas. Based on the available data, unlike the age and the place of residence, the number of children raised in the household did not substantially affect participation in the payment moratorium (Figure 9). 


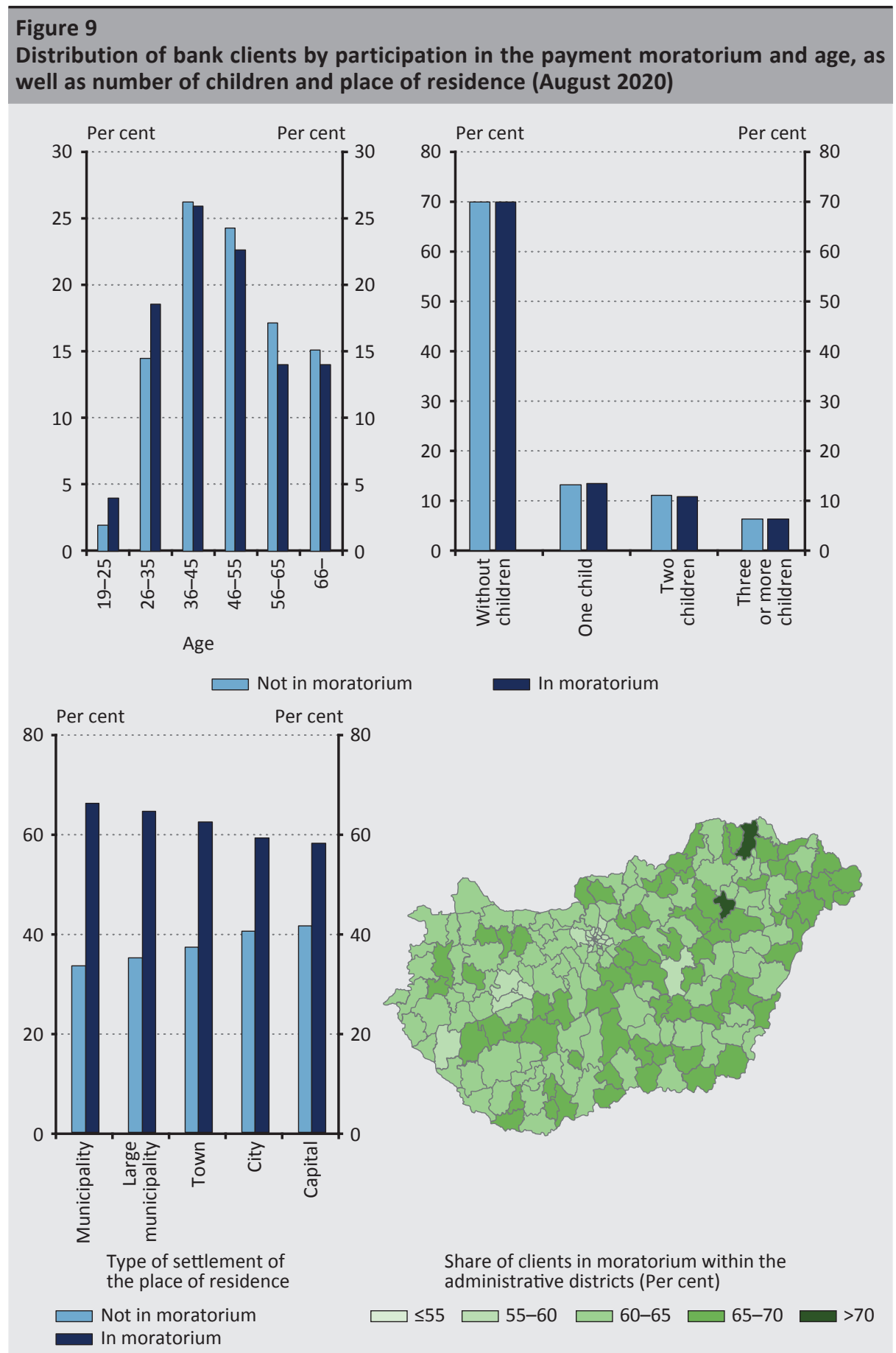

Note: Only banking sector and natural persons as debtors (excluding private entrepreneurs and smallscale agricultural producers). 
The income and labour market characteristics of clients entering the payment moratorium also confirm that a higher proportion of those with reduced shock resilience used the payment moratorium. The proportion of clients participating in the payment moratorium is higher among those who have low educational attainment, or are part-time workers or job seekers, and are more indebted and have low savings (Figure 10).

- Educational attainment: According to the MNB survey, among those entering the payment moratorium, the proportion of clients who have at most a secondary school degree, considered as low educational attainment, is 61 per cent, while this proportion is 44 per cent among clients who did not enter the payment moratorium.

- Status of labour market: There are four times as many unemployed and twice as many part-time workers among the clients who entered the payment moratorium, compared to debtors who did not participate in the payment moratorium.

\section{Figure 10}

Distribution of bank clients by use of the payment moratorium and level of education attained by the highest earning people of the household and their labour market status (August 2020)

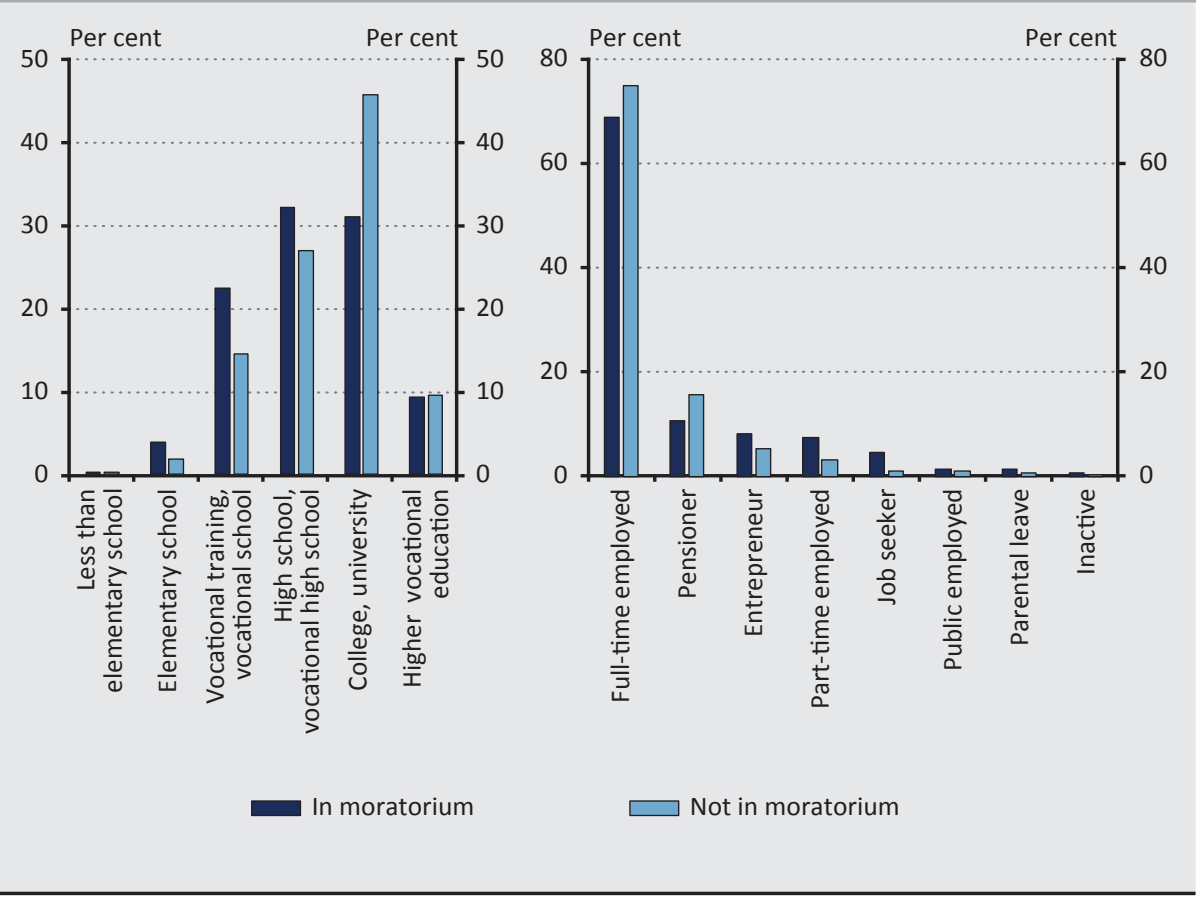


- Income situation: Based on the extraordinary reporting ordered by the MNB, the income of bank clients at the sector level was similar among the clients entering the moratorium and those opting out of it (Figure 11). The median income fluctuated between HUF 260,000 and 280,000 in net value for both the clients entering the moratorium and those opting out of it. At the same time, taking into account the indebtedness of clients, it becomes apparent that the proportion of clients with higher debt and thus a higher instalment, compared to their income, is more significant among those entering the payment moratorium (Figure 11). More than 220,000 clients, approximately 14 per cent of clients participating in the payment moratorium, have debt exceeding their annual income more than four times, which is nearly twice the value of clients who opted out of the payment moratorium. Highly indebted clients were more likely to stay in the payment moratorium, as Gaffney - Darren (2020) also established using data for Ireland.

\section{Figure 11 \\ Bank clients according to their use of the payment moratorium, income and indebtedness in relation to their income}

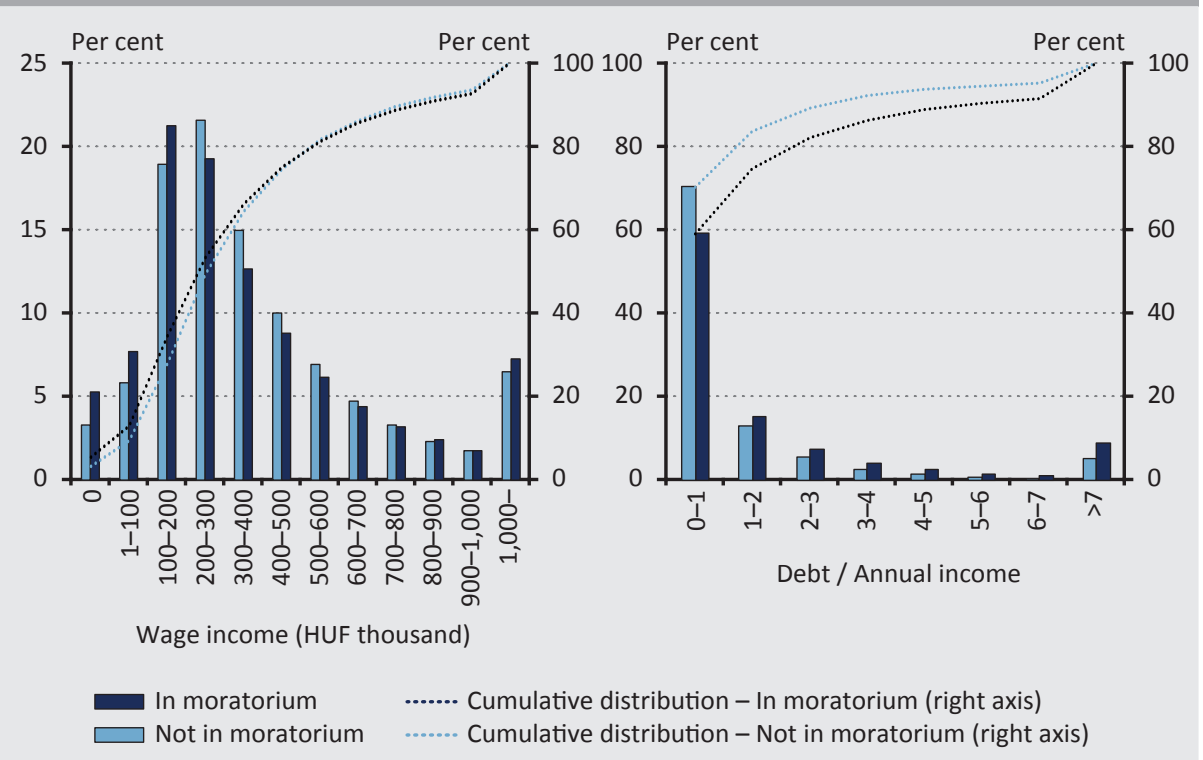

Note: The total debt/annual income ratio was examined among bank clients with wage credits in December 2019 based on their debt stock in August 2020 and the annualised average of their average wage credits in the second quarter of 2020. Regarding the total debt of the clients, in case of co-debtors the total debt of all parties assuming a joint commitment was considered.

- Savings: According to their self-assessment, households remaining in the payment moratorium have lower savings compared to households that opted out of the payment moratorium. Of households in the payment moratorium, 83 per cent have sufficient savings for up to three months, while this proportion is lower by 
21 percentage points, amounting to 62 per cent in case of performing households (Figure 12).

Figure 12
Savings of households remaining in and opting out of the payment moratorium

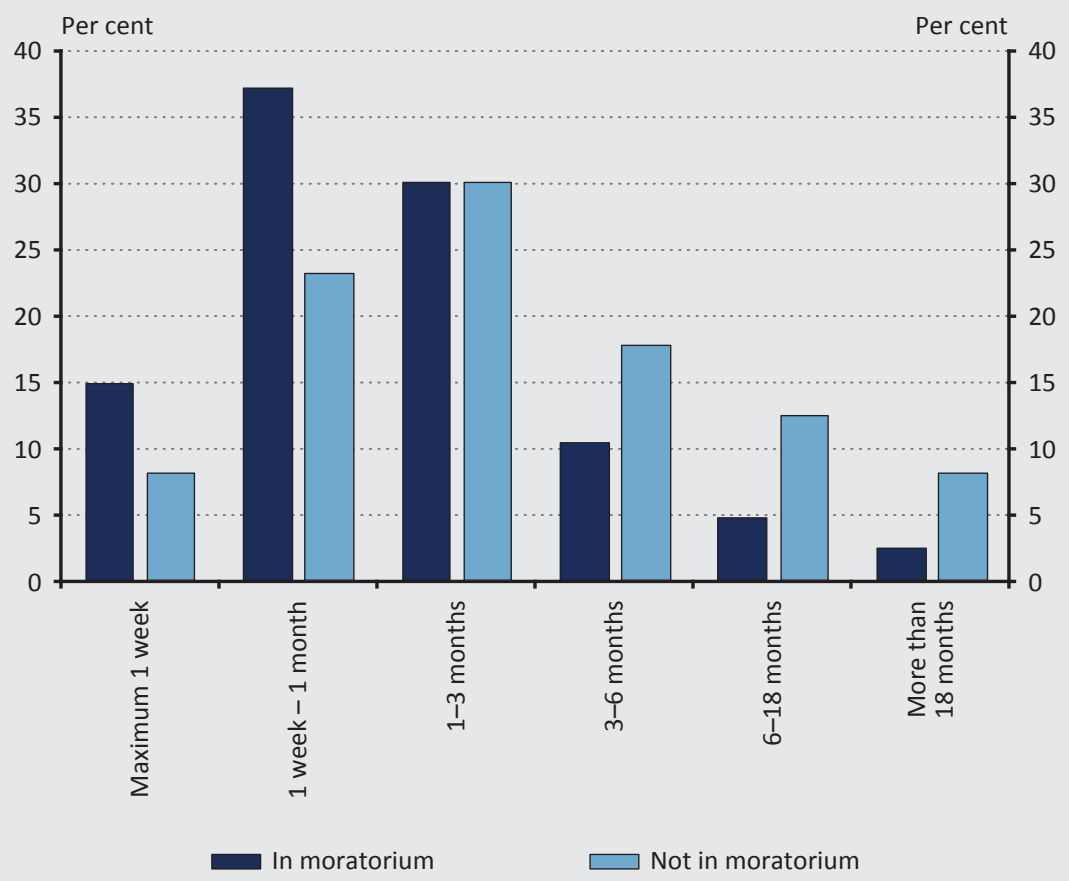

Note: Question: If all members engaged in paid employment lost their jobs in your household, for how long would the household be able to maintain its current standard of living?

We estimate that the payment moratorium will improve the liquidity position of households by approximately HUF 580-620 billion until the end of 2020, i.e., by $1.2-$ 1.3 per cent of 2019 GDP. The liquidity effect of the moratorium stems mainly from the instalments of mortgage loans amounting to about HUF 300-310 billion and personal loans of about HUF 160-170 billion remaining with households (Figure 13). In addition to personal and mortgage loans, the potential instalment savings from overdraft and credit card debts are also significant. According to the current market practice, it results in HUF 50-55 billion of savings, assuming 5 per cent repayment of outstanding capital amount per month. In 2020, the amount remaining with households due to the payment moratorium contributed significantly to mitigating the potential negative effects of the coronavirus pandemic. 


\section{Figure 13 \\ Estimated liquidity impact of the payment moratorium by product type (HUF billion)}

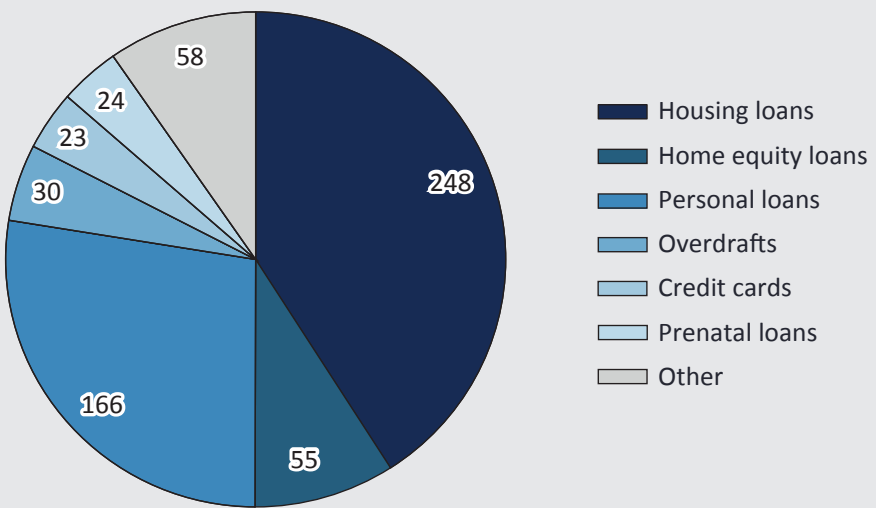

Note: Only banking sector and natural persons as debtors (excluding private entrepreneurs and smallscale agricultural producers). In the case of prenatal loans, the liquidity effect of the payment moratorium also includes the effect of the suspended repayment due to having children.

Source: $M N B$

\subsubsection{Potentially vulnerable retail clients}

In order to identify the potentially vulnerable client segment directly impacted by the effects of the coronavirus pandemic, we examined the changes of the income situation and labour market position of the clients, and their responses in the questionnaire on their vulnerability to the pandemic.

Compared to the first quarter of 2020, the average monthly income of approximately 47 per cent of clients not continuing their repayment obligations decreased to some extent in the second quarter of 2020 (Figure 14). The income of one third of these clients decreased by more than 30 per cent. Thus, according to our estimation, 240,000 household debtors using the payment moratorium can be considered vulnerable based on changes of their income situation. 


\section{Figure 14}

Distribution of bank clients based on quarterly change in the average wages credited to their bank accounts between the first and second quarter of 2020

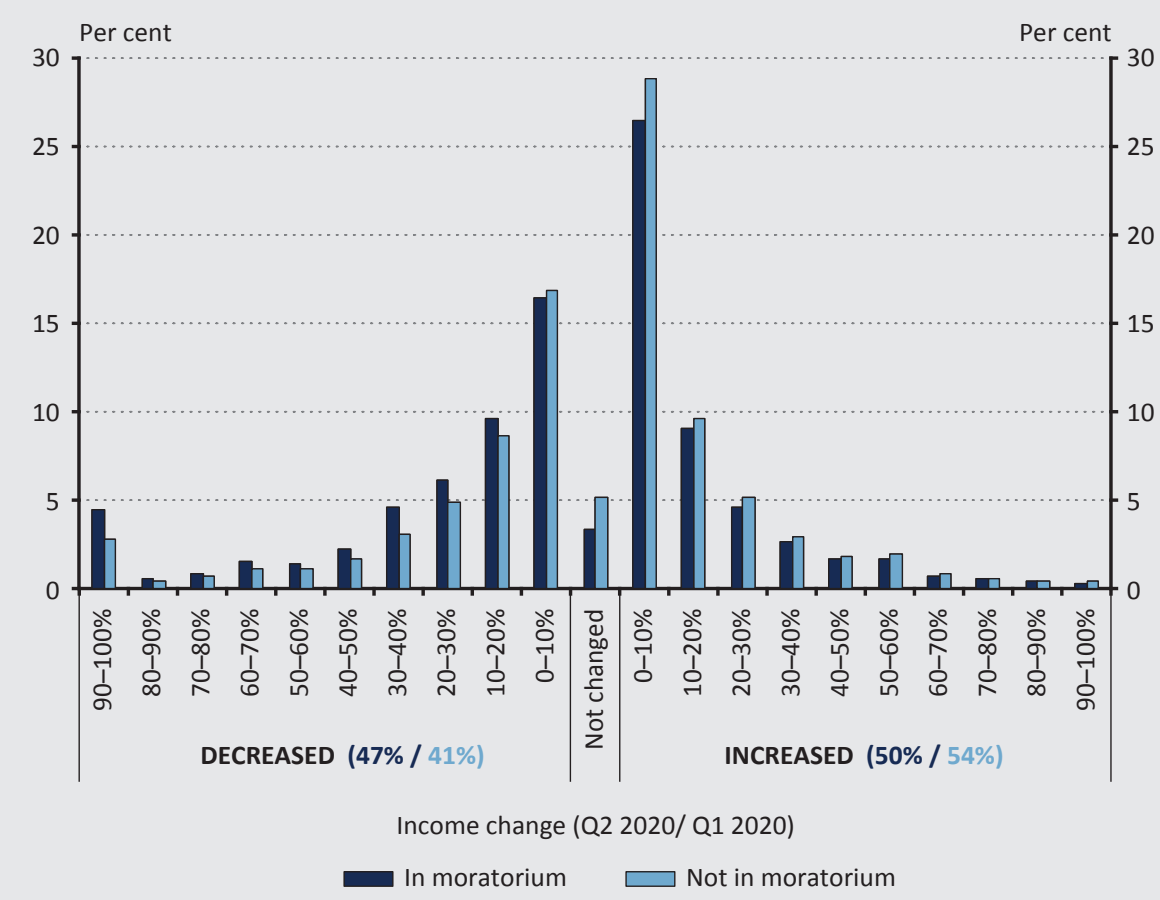

Note: Only banking sector and natural persons as debtors (excluding private entrepreneurs and smallscale agricultural producers). An estimate prepared based on the income information of bank clients with wages credited in December 2019.

According to the MNB's survey, in more than 11 per cent of households entering the payment moratorium the highest earning member worked as an employee in February 2020, and their labour market status has deteriorated since then, while the same proportion for those opting out of the payment moratorium was 3 per cent. Of the 11 per cent of debtors using the payment moratorium and experiencing deteriorating labour market conditions, 7 percentage points became part-time employees, 4 percentage points became job seekers and 0.5 percentage points became public sector employees (Figure 15). As a result, our estimate shows that around 180,000 clients entering the payment moratorium can be considered financially vulnerable due to the deterioration in their labour market status. 


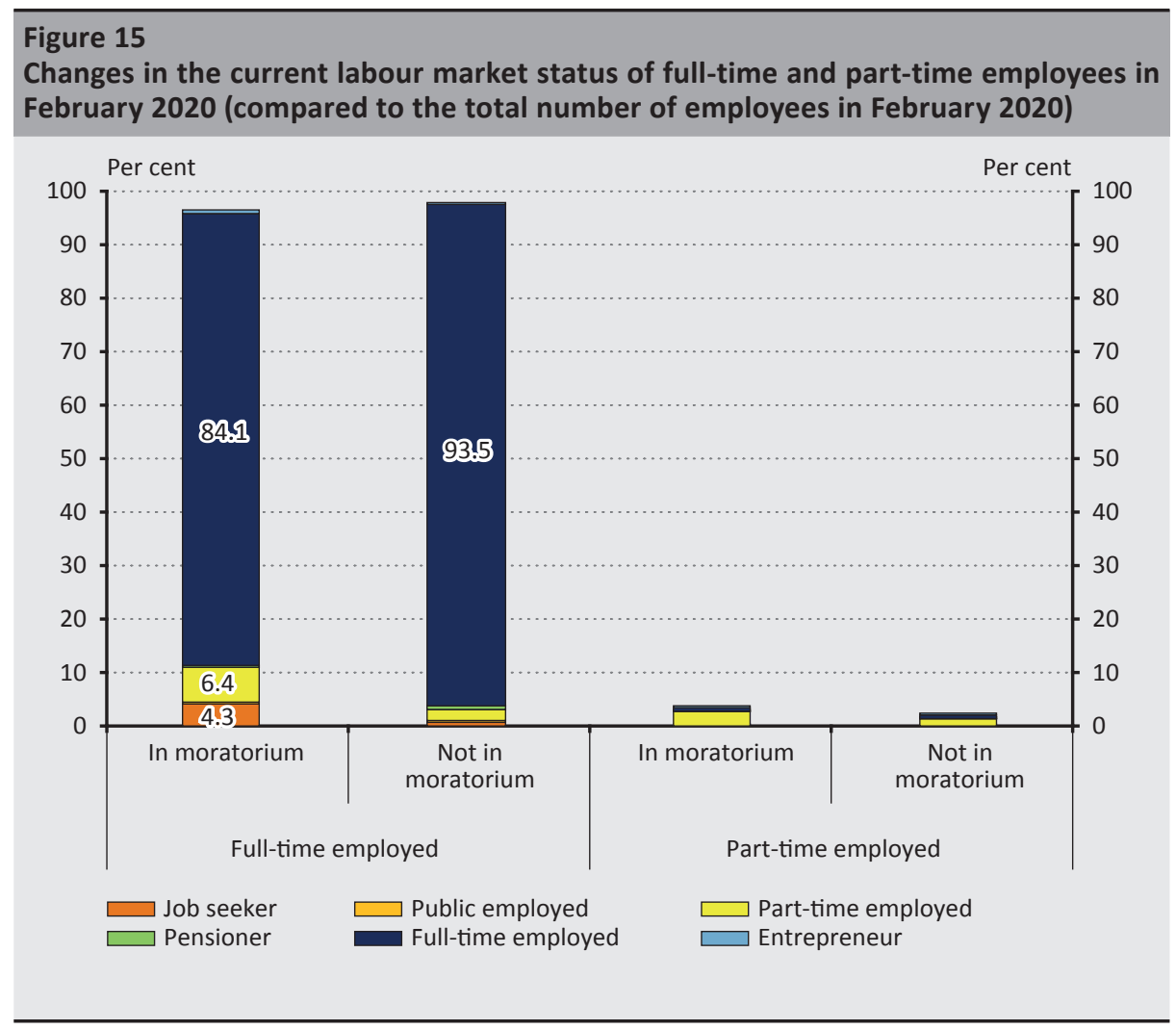

According to the MNB's survey, more than 53 per cent of households staying in the moratorium expect repayment difficulties in 2021 (Figure 16). Nearly three quarters of them claimed that they would already face repayment difficulties in the absence of a payment moratorium. However, a significant proportion of them defined themselves as households with potential repayment difficulties despite their unchanged or rising income, which draws our attention to the occurrence of moral hazard. Therefore, maintaining a broad moratorium over the long term is expected to increase default risks in the future. Based on the survey, almost one third of clients expecting repayment difficulties and using the moratorium claimed to have a significant decrease in their income, and thus a group of about 270,000 people may be considered vulnerable according to their self-assessment. Two thirds of this vulnerable client group (Figure 17), or 180,000 clients could maintain their current standard of living for up to a month, so they can be considered particularly risky. This ratio is significantly higher compared to the proportion of households with no significant savings observed in previous years. According to Boldizsár et al. (2016), about 40 per cent of households have no significant assets. 


\section{Figure 16}

Distribution of households using the moratorium according to their expectations of repayment difficulties and changes in their income

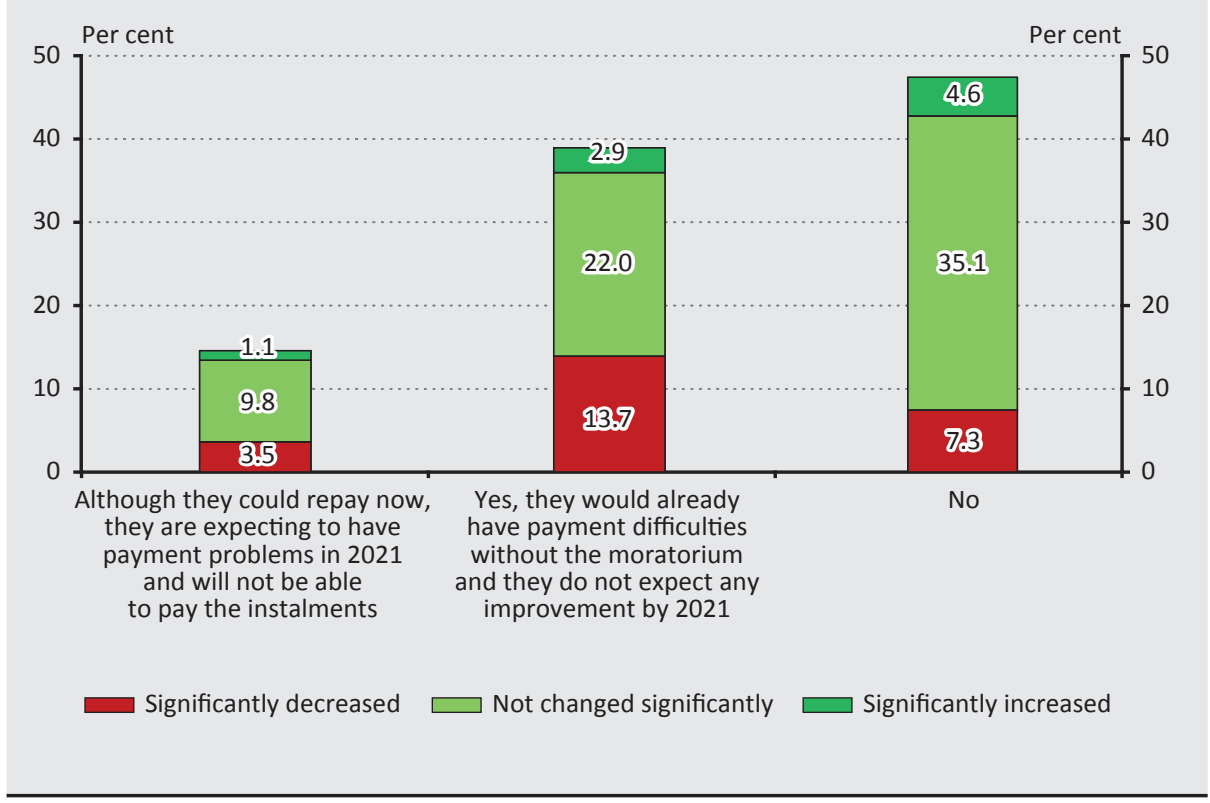

\section{Figure 17}

Distribution of the savings of households using the moratorium and claiming to have repayment difficulties in the absence of a moratorium, supposing an event when all members in paid employment lost their jobs

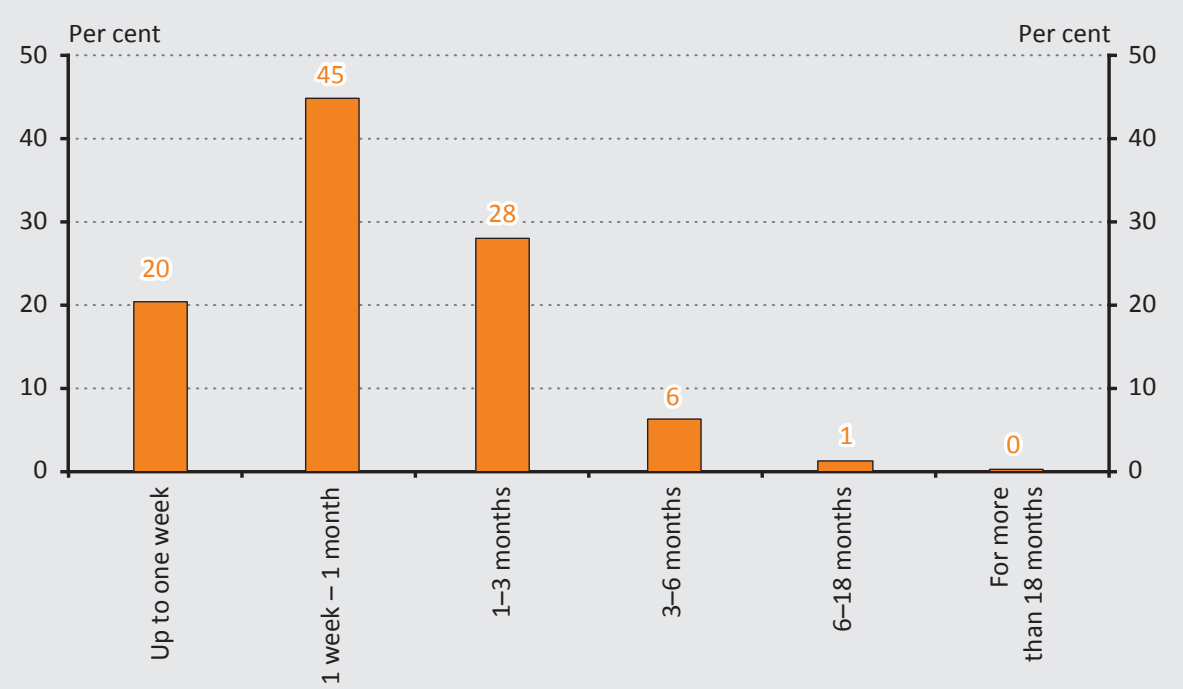

Note: Question: If all members engaged in paid employment lost their jobs in your household, for how long would the household be able to maintain its current standard of living? 
All in all, the possibility of the moratorium was used by a larger number of clients who were more vulnerable in terms of demographics, income and wealth. The estimated group of potentially vulnerable household clients directly impacted by the effects of the coronavirus pandemic accounts for around 180,000-270,000 people.

\subsubsection{Corporate segment}

Based on the data from August 2020, use of the moratorium in the corporate segment, as a proportion of the outstanding loan portfolio, amounted to approximately 40 per cent, i.e. HUF 3,700 billion in the credit institution sector and affected nearly 50,000 companies. Our whole corporate analysis applies to the credit institution sector; the loan portfolio under moratorium belonging to noncredit institutions can be estimated at about HUF 600 billion. During the analysed period, from May to August, use of the moratorium among corporate clients fell by about 10 percentage points. This may be partly due to the fact that with the end of the first wave of the coronavirus, some companies may have decided to continue the repayment of their loans again due to the lower level of uncertainty and rising demand. Despite the lower utilisation, by the end of 2020 the payment moratorium is estimated to have improved the liquidity situation of companies by about HUF 1,100 billion, i.e. by $2.3-2.4$ per cent of 2019 GDP.

The size of the company has a significant effect on use of the moratorium, as a smaller proportion of larger enterprises opted for the moratorium (Figure 18). Micro-companies and SMEs participated in the moratorium for more than half of their transactions during the analysed period, while the scope of large enterprises entering the moratorium was 10-15 percentage points lower. ${ }^{7}$ Among loans with outstanding amounts above HUF 1 billion, use of the moratorium was still 12 per cent lower in June and almost 10 per cent lower in August than in the case of loans with outstanding amounts below HUF 1 billion. Of the contracts participating (outstanding loan portfolio) in the moratorium, 45 per cent ( 20 per cent) are microcompanies, 23 per cent ( 18 per cent) are small companies, 14 per cent ( 24 per cent) are medium-sized companies, and 18 per cent (38 per cent) are large companies.

\footnotetext{
${ }^{7} \mathrm{~A}$ higher participation of SME clients in the moratorium in Ireland was also observed by Duignan and McGeever (2020).
} 

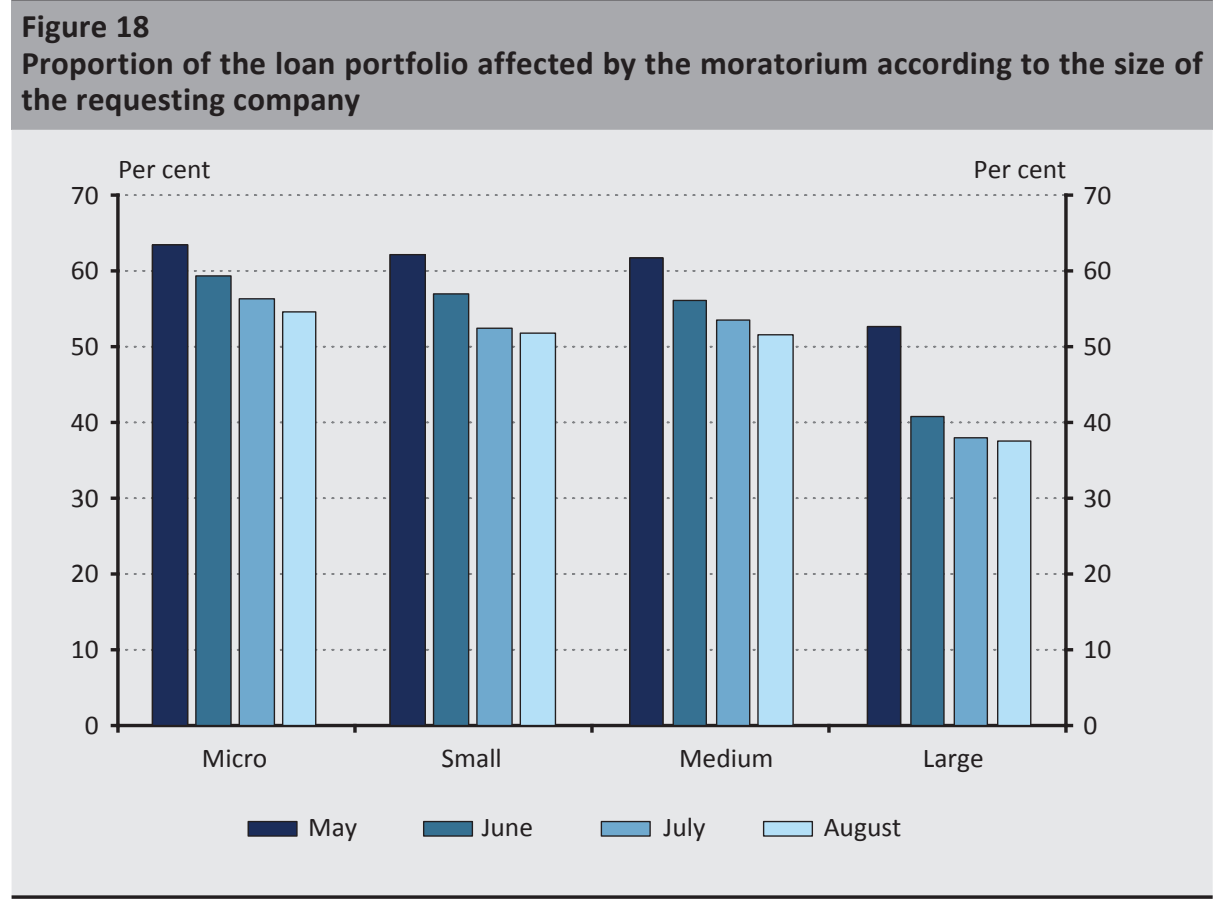

The ten sectors with the largest loan portfolios account for about 94 per cent of the corporate loan portfolio and show higher variability in terms of participating in the moratorium (Figure 19). The hotel and restaurant sector has the highest proportion, with above 85 per cent of clients participating in the moratorium. This high utilisation rate is likely to be linked to the negative effects of the coronavirus pandemic on the real economy and the quarantine measures affecting this sector the soonest and most directly; therefore, the moratorium could provide immediate aid to companies operating in this sector to address their liquidity problems. The moratorium was used the least in the construction and administration sectors, where it remained below 40 per cent in both June and August. In the manufacturing industry, which has the largest loan portfolio and accounts for almost one quarter of the total loan portfolio, use of the moratorium is similar to the population mean, i.e. 52 per cent in June and 45 per cent in August. Based on the geographical distribution, there are smaller and larger deviations in the utilisation of the moratorium at the county level, but the aggregate ratios regarding use in Budapest and outside of Budapest are in accordance with the population mean. 


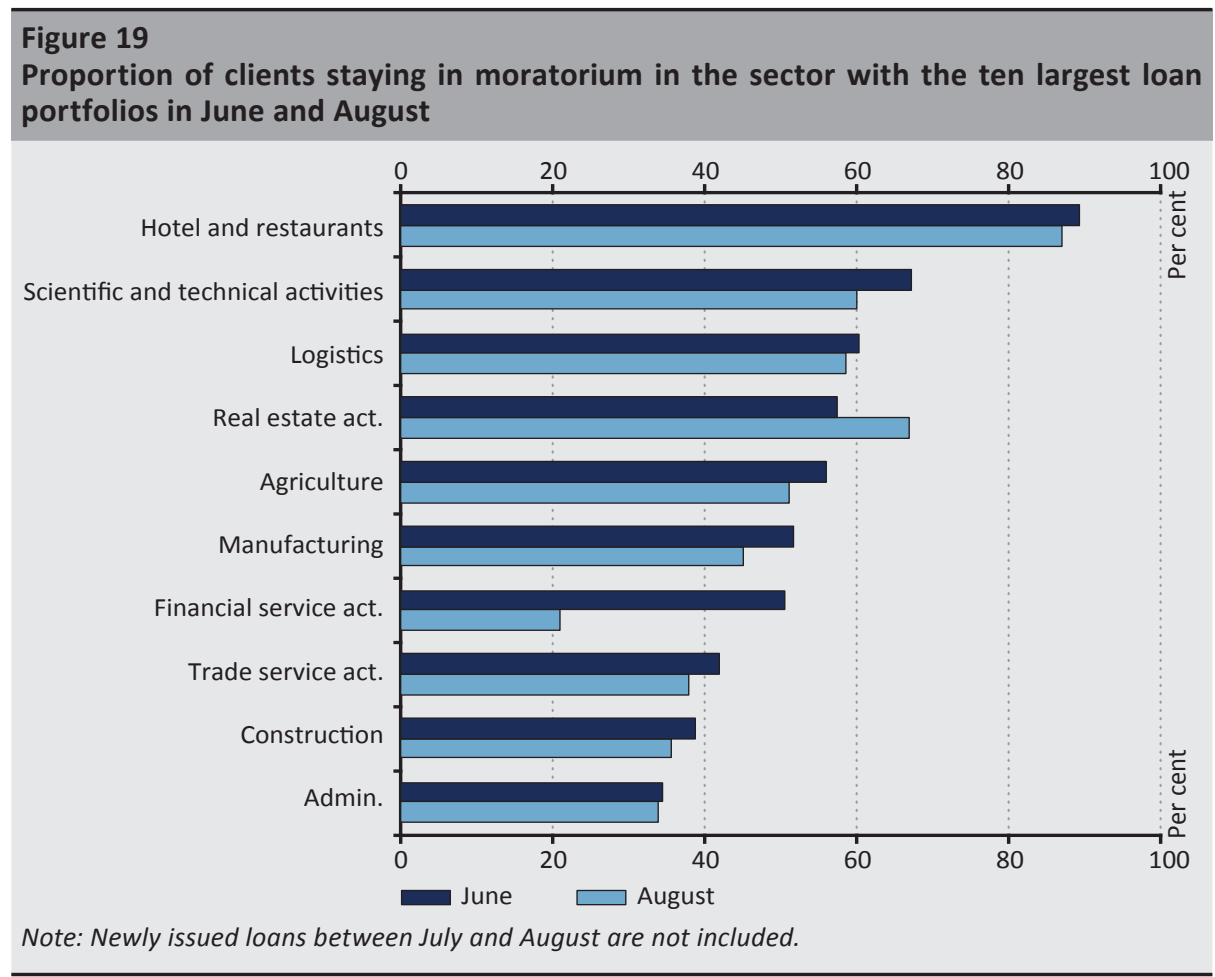

The findings of the MNB's questionnaire survey also confirm the above mentioned characteristics of corporate debtors participating in the moratorium. The questionnaire was completed by a total of 1,165 corporate debtors, of which 940 responded to the question on the use of the moratorium ("Do you apply the payment (repayment) moratorium valid until the end of 2020 for any of the company's existing loans?"). 501 companies participated in the moratorium, while 439 companies decided to continue repayments, and thus our analysis was carried out on these companies. The sectoral distribution of the responding companies differs slightly from the actual data reported on the contribution to GDP and the number of companies, too (Figure 20). According to the actual data from August 2020, although 26 per cent of registered enterprises operated in the industry of agriculture, forestry and fishing ${ }^{8}$ and 4 per cent of 2019 GDP was related to this industry, ${ }^{9}$ in the survey 16 per cent of the responding companies were related to this industry. In spite of the limited sectoral representativeness, the share of the responding companies participating in the moratorium shows road correspondence with the population mean, as 501 companies entered the moratorium for at least one of their loans, corresponding to a 53 per cent utilisation rate.

\footnotetext{
${ }^{8}$ Number of registered enterprises by industry - GFO'14. https://www.ksh.hu/docs/eng/xstadat/xstadat infra/e_qvd019a.html. Downloaded: 20 November 2020.

${ }^{9}$ Value and distribution of gross value added by industry (1995-). https://www.ksh.hu/docs/eng/xstadat/ xstadat_annual/i_qpt002d.html. Downloaded: 20 November 2020.
} 


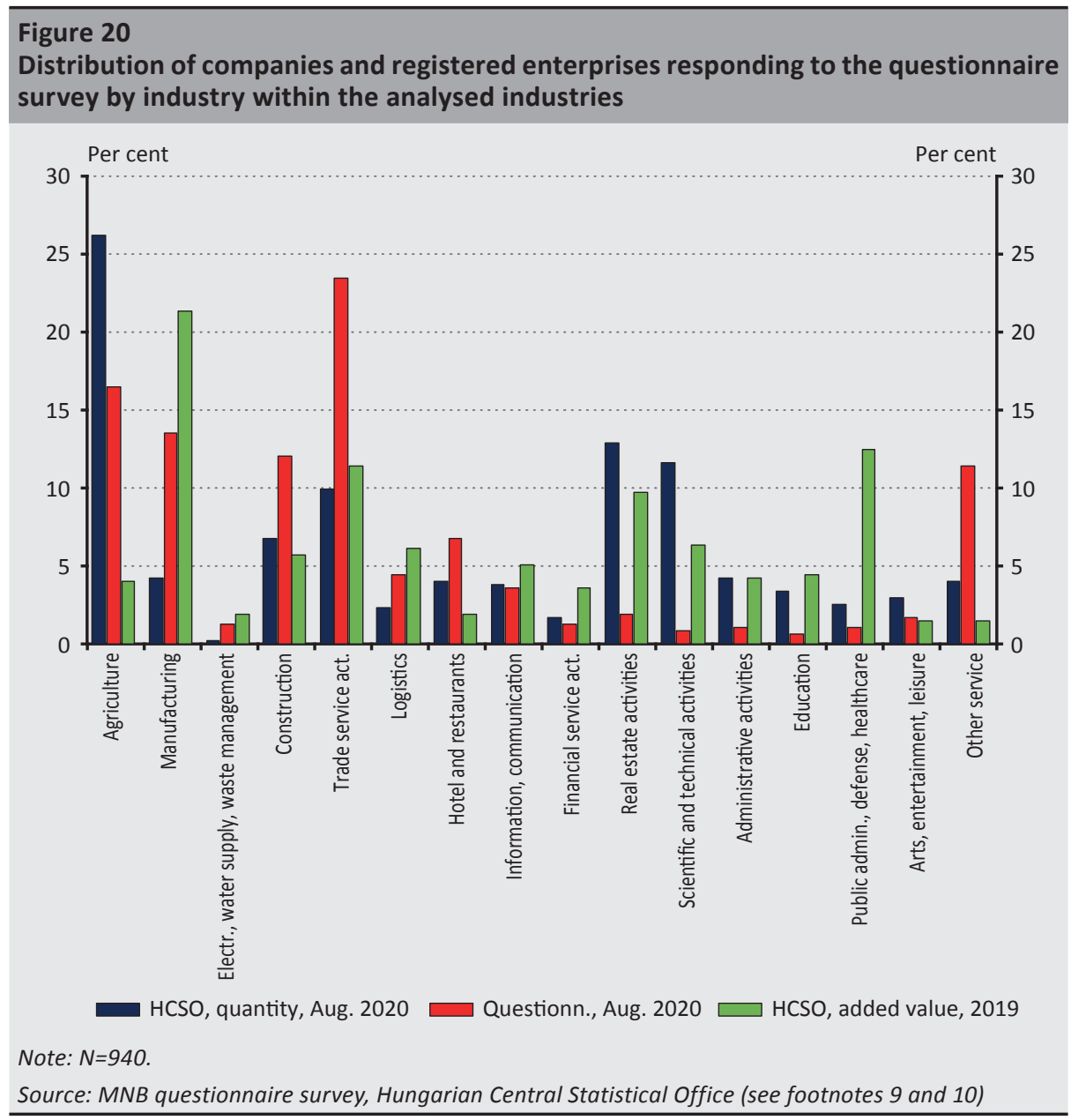

According to the questionnaire, the moratorium provided significant help for companies in tackling their temporary liquidity problems, as 30 per cent of companies participating in the moratorium responded that they could not have repaid their loans, and another 40 per cent stated that they could have only partially repaid their loans if they had not participated in the moratorium. Most companies used the funds freed up to cover their temporary liquidity goals: almost two thirds chose this option in the questionnaire survey, while less than 30 per cent of companies indicated all other goals separately (investment, savings/reserves, wage payments).

According to the survey, companies participating in the moratorium were relatively more indebted and expected a more significant decline in average revenue in 2020, which was further supported by the fact that they tended to operate in industries more impacted by the negative economic consequences of the pandemic. 
Of the surveyed companies, 61 per cent responded that their outstanding borrowing on 18 March 2020 was below 25 per cent of their annual revenue in 2019, 23 per cent responded that it was between $25-40$ per cent, and 17 per cent responded that it exceeded 40 per cent. Among companies participating in the moratorium, the share of low-debt companies was only 53 per cent, while the share of companies opting out of the moratorium with outstanding borrowing below 25 per cent of their annual revenue in 2019 was 70 per cent (Figure 21). The share of companies entering the moratorium was already higher, i.e., 26 per cent belonged to the value of 25-40 per cent, while among companies opting out of the moratorium, this share was only 19 per cent. An even higher proportion of more significantly indebted companies with borrowing amounting to at least 40 per cent of their revenue in 2019 participated in the moratorium: 21 per cent of companies entering the moratorium can be classified here, while the share of companies opting out of the moratorium was slightly more than half of this, as 12 per cent of these firms can be considered significantly indebted.
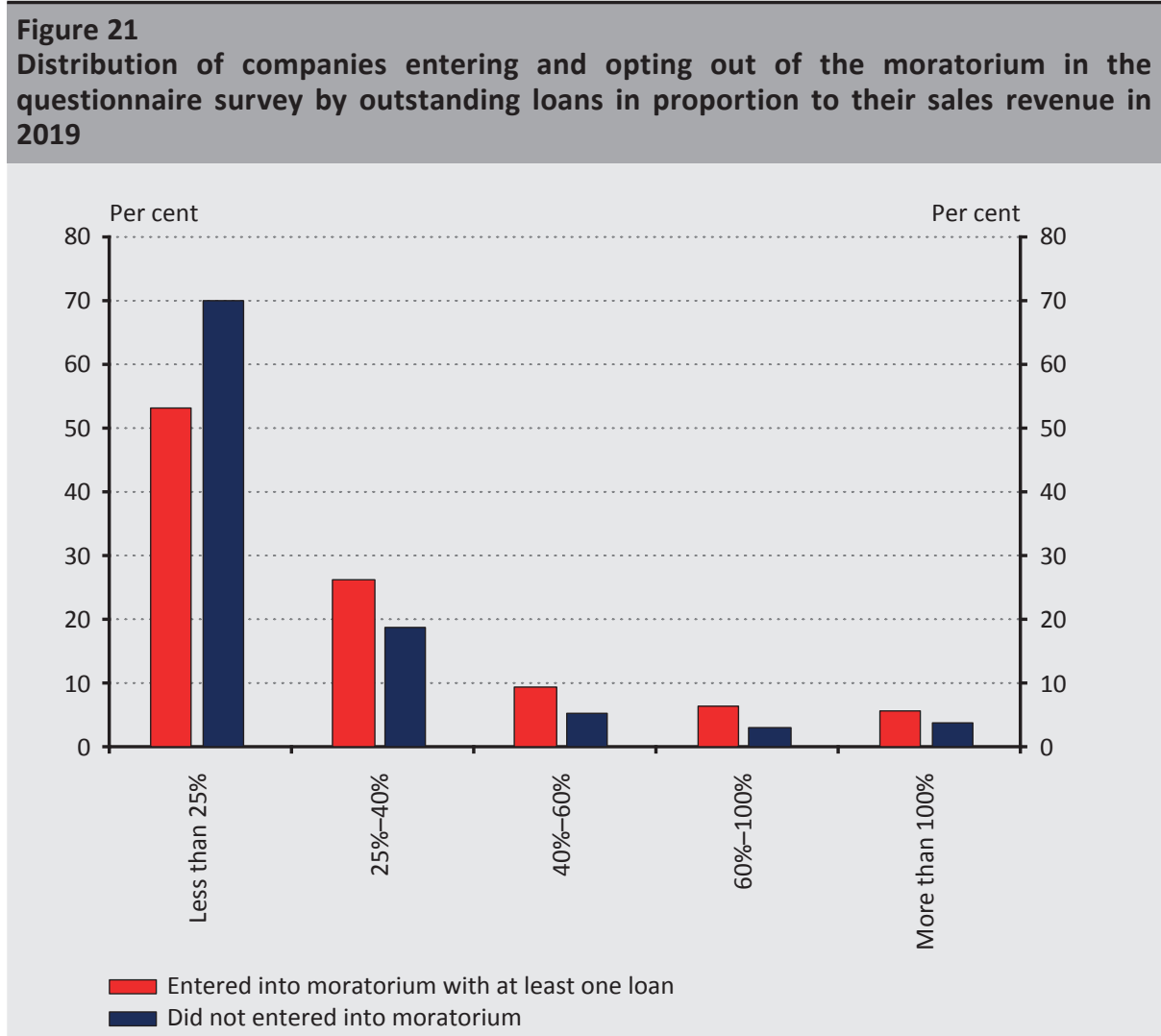

Note: $N=940$, of which 501 companies benefited from the moratorium for at least one loan, while 439 did not. 
According to the questionnaire survey by the MNB, almost one in five companies claimed to have a significant decrease in sales revenue in 2020. When the moratorium was introduced, 18 per cent of companies with a loan said they expected this year's sales to be at least 30 per cent lower than last year due to the economic effects of the pandemic. Companies participating in the moratorium foresaw a larger decline in revenue in 2020 than those opting out of the programme. While 24 per cent of those participating in the moratorium expect their incomes to fall by at least 30 per cent this year compared to last year, the same ratio for companies continuing repayments is only 12 per cent. At the same time, a significant proportion of companies participating in the moratorium do not expect their revenue to drop: 34 per cent of them indicated no change or an increase. However, this proportion was significantly higher, at 53 per cent, for those opting out of the programme. The tourism and hospitality sector has been hit hardest by the pandemic: one half of these companies expected to experience at least a 30 per cent decrease in sales in 2020 (Figure 22). Within the sector, almost all companies with a significant drop in revenue benefit from the moratorium, and there are only a few exceptions.

\section{Figure 22}

Proportion of companies losing at least $\mathbf{3 0}$ per cent of their revenue in 2020 compared to the proportion of all respondents, distributed by sectors

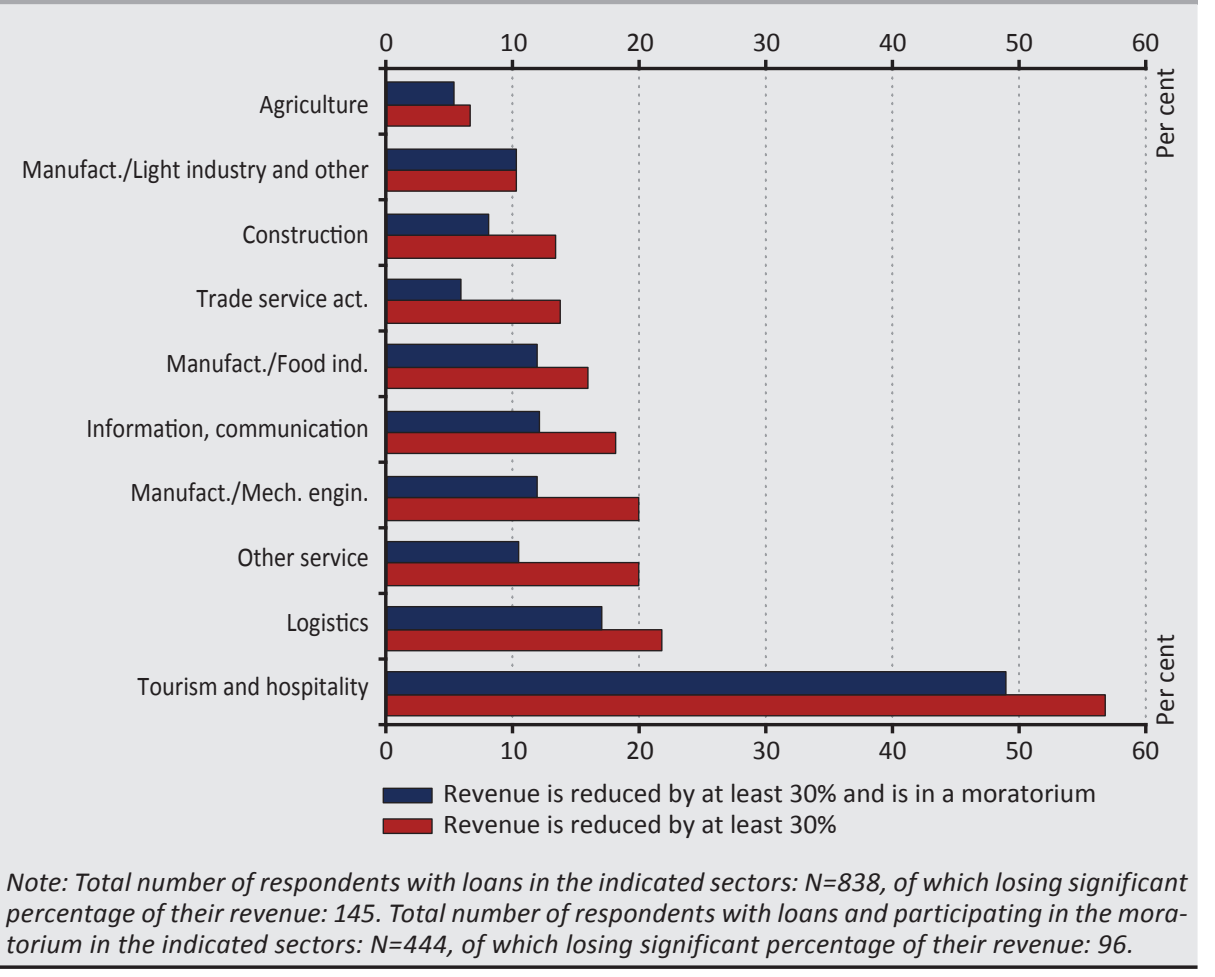




\subsubsection{Moratorium in vulnerable industry sectors}

In the Financial Stability Report published in May 2020, the MNB identified the sectors most exposed to the negative effects of the coronavirus crisis. The sectors immediately affected on account of the pandemic and the related measures, shutdowns, restrictions and isolation efforts (for example, the entire tourism and hospitality industry sector) were classified as directly vulnerable. Subsectors affected by second-round effects from the containment measures, such as the decline in aggregate demand (e.g. passenger vehicle manufacturing) were classified as indirectly vulnerable (See MNB (2020b:73-76) for detailed classification). Similar to March 2020, the data from August showed that the loan portfolio of companies operating in vulnerable industries accounted for roughly one third of the total loan portfolio, with their use of the moratorium being higher than average. Companies operating in a vulnerable sector typically have fewer employees compared to the general number in the corporate sector. Among companies operating in vulnerable sectors, the weighting of small- and medium-sized enterprises was above the population mean.

Within the vulnerable sectors, we assessed companies as being particularly risky where the liquidity situation (personnel costs/funds $>0.5$ ) and indebtedness (debt/EBITDA $>1$ or negative) are relatively stretched and they participated in the moratorium. One tenth of the total corporate exposure is considered to be particularly risky in relation to vulnerable sectors. Due to the protracted pandemic situation, some of the companies operating in sectors with less direct or indirect exposure to the coronavirus may also have problems repaying loans after the end of the payment moratorium. Therefore, the loan portfolio of companies operating in non-vulnerable sectors but which are in a significantly tight financial position (debt/EBITDA $>4$ or negative and personnel costs/funds $>2$ ) and are participating in the moratorium was also identified as risky, accounting for 6 per cent of the total corporate loan portfolio. All in all, the particularly risky loan portfolio accounts for 15-20 per cent of the corporate loans of credit institutions, which is similar to the data in July (cf. MNB 2020c: 31-32). According to the MNB's survey, a similar ratio can be identified for the risky loan portfolio (Figure 23): 19 per cent of the 940 companies responding to the questionnaire said they would not be able to repay at present and do not expect improvement in the future, and another 12 per cent of companies said they would be able to repay at present, but based on their current expectations of turnover and revenue, they will not be able to in 2021. According to the questionnaire survey, among the companies participating in the moratorium, we can clearly distinguish the ones which are in need of a moratorium or the ones which are only utilising it: three out of four companies which entered the moratorium and experienced more serious liquidity problems in the spring claimed that they are still having repayment difficulties and do not expect any improvement in the future. Of the companies which claimed they would be able to 
fully perform in spring but are still participating in the moratorium, only 20 per cent expect repayment difficulties now or in the future. The high degree of persistence in the current situation and expectations may be due to the specific nature of the coronavirus situation: the quarantine measures introduced in spring in relation to the virus situation affected each sector to a different extent, mostly depending on whether the sector is able to operate via digital platforms and teleworking. The prospects of each sector may be strongly influenced by the continuation of maintaining physical distance, so the extent and pace of sectoral recovery may show significant differences.

\section{Figure 23 \\ The relationship between payment difficulties and creditworthiness}

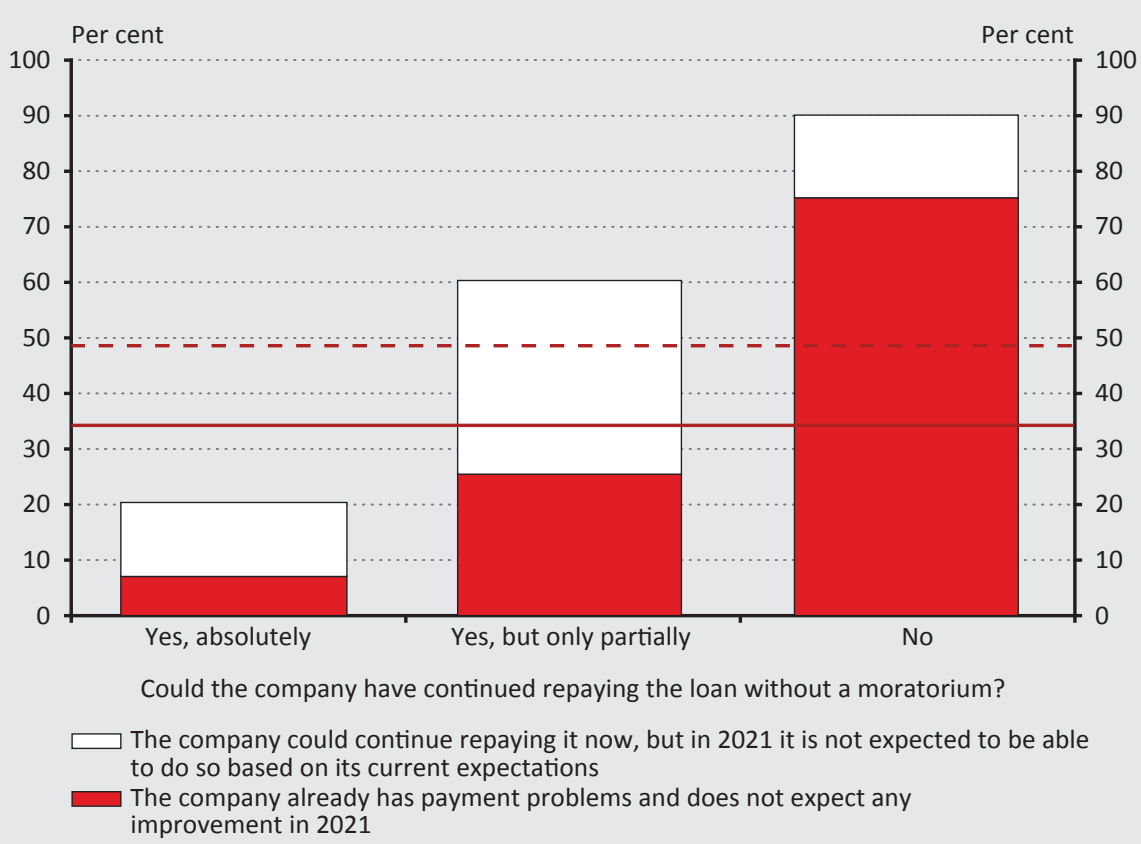

Note: Among the 501 companies benefiting from the moratorium, the proportion of companies using the moratorium and claiming to have repayment difficulties (in the future) is indicated with a (dashed) red line. The figure shows respondents with payment difficulties, the remaining respondents did not have a repayment problem at the time of completing the questionnaire and did not expect this in the future.

\subsection{Effects of the payment moratorium on the banking sector}

\subsubsection{Profitability}

The payment moratorium was able to provide significant excess liquidity to market participants at a moderate cost. Under the legislation on the payment moratorium, the interest due during the moratorium period is not capitalised, but the accrued interest, together with the instalments due in the remaining term, shall be paid after 
the expiry of the payment moratorium annually, in equal instalments over the term of the loan. At the same time, however, the banking system is suffering losses due to the decrease in present value. According to our estimates, the payment moratorium may have caused banks a loss of about HUF 25-30 billion in 2020, based on the utilisation data in August. At the same time, the realised loss is partially offset by the decreasing credit risk due to the moratorium, the slower rate of deterioration in portfolio quality and the general stimulus effect of the moratorium on the economy. However, maintaining a moratorium without a confirmed need may increase the moral hazard of customers over the long term, which could lead to long-term losses for the actors in the banking system.

\subsubsection{Loan loss provisioning}

Excessively long-term availability of a payment moratorium may obscure the real repayment capacity of clients and render prudent loan loss provisioning more difficult for credit institutions. Examining the distribution of loan portfolios in terms of impairment categories (see Figure 24), it can be concluded that in the retail segment, loans under the moratorium and loans outside the moratorium do not show a significant difference. Handling retail loan portfolio independently from the moratorium in terms of impairment classification suggests that the payment moratorium may mask the real repayment capacity of clients over the longer term, and that an actual need for loan loss provisioning will only arise later, after the expiry of the moratorium. The payment moratorium has a larger influence on banks' assessment of changes of corporate credit risk than on retail exposures. In the case of companies, it can be observed that credit institutions categorised the loan portfolio in moratorium as higher credit risk to a greater extent. This may be explained by the fact that banks have more information on the credit risk of more closely monitored corporate clients, and that companies are generally more active in approaching their creditor bank in the event of repayment problems. However, the credit risk of clients participating in the payment moratorium in the corporate segment can only be assumed to be an estimate with significant uncertainty, and major corrections may even be required after the moratorium. 


\section{Figure 24}

Distribution of loan portfolios entering or opting out of the moratorium by client segment and impairment classification (August 2020)

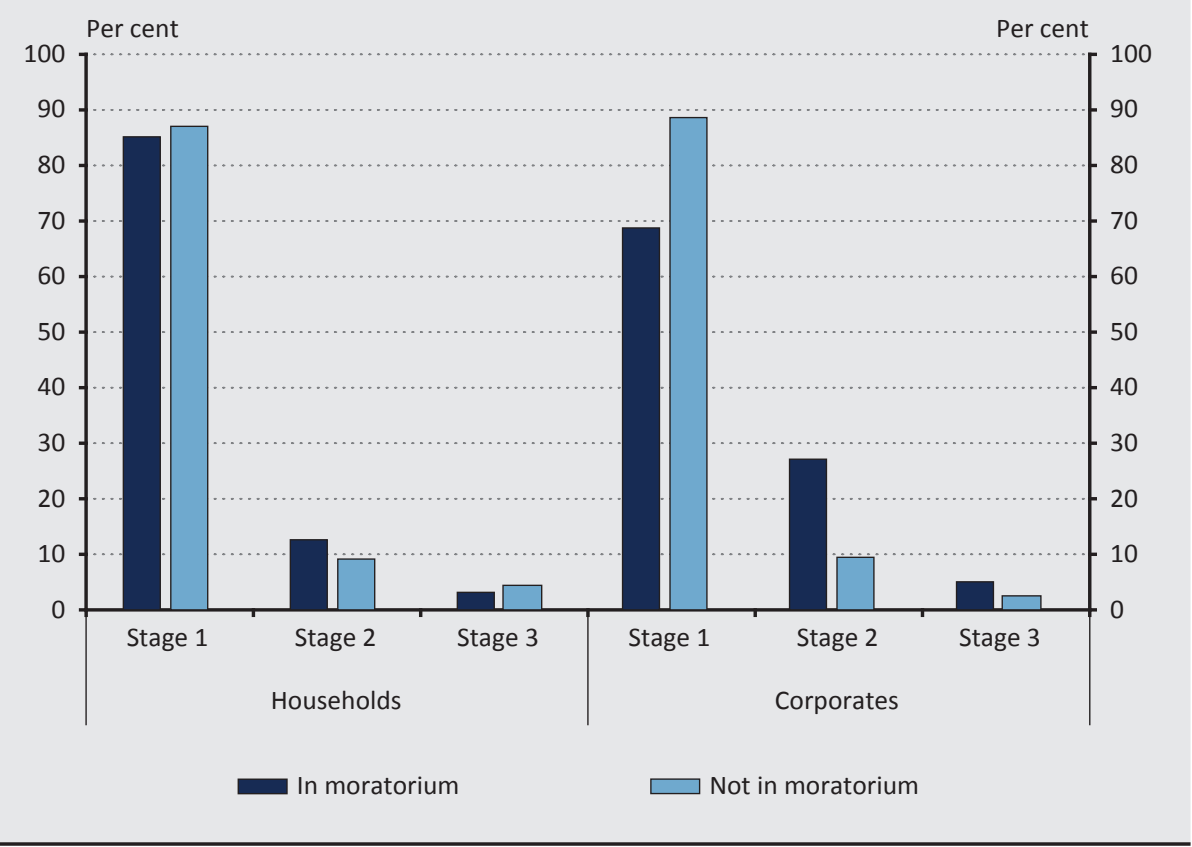

\section{Extension of the payment moratorium}

The prolonged duration of the coronavirus pandemic and its re-intensification experienced from September 2020 further worsened the economic prospects and necessitated the introduction of further containment measures. In order to counteract the potential negative economic effects of the protracted pandemic, the Hungarian government decided to extend the payment moratorium by 6 months for loans disbursed by 18 March 2020. According to the government's decision, the payment moratorium will remain in effect until 30 June 2021 under the same conditions for debtors which entered the payment moratorium, while debtors which opted out of the moratorium shall inform their creditors of their intention to use the payment moratorium by written or electronic form.

Assuming that the participation rates of the payment moratorium in August are maintained for the entire 6-month period of the extension, the measure may provide approximately HUF 1,100-1,200 billion of excess liquidity for the debtors in moratorium. According to our estimates, household clients benefit from about HUF 420-460 billion and corporate customers from about HUF 680-740 billion of excess liquidity remaining with economic actors. Consequently, the payment 
moratorium may leave about 2.3 per cent of 2019 GDP to market participants in 2021, thus alleviating their liquidity difficulties and helping to restore economic activity as early as possible.

Similar to the measure in 2020 , the extension of the moratorium will have an adverse effect on bank profitability due to the change in the present value of loans. The six-month extension may result in an additional loss of approximately HUF 10-15 billion for banks, due to the decreased present value of loans. Nonetheless, the potential loss can be offset by the adequate capital position of the banks. The MNB also supported the lending capacity by releasing capital requirements with a number of measures.

However, the vast majority of the loan portfolio expected to participate in the extension of the payment moratorium will no longer be subject to the preferential loan loss provisioning rules, which will result in an additional obligation of loan loss provisioning by the banks. Based on the recommendation of the European Banking Authority (EBA 2020b) and the information provided by the MNB, ${ }^{10}$ the extension of the moratorium taking effect after September 2020 is considered to be new payment rescheduling. In the case of the moratorium extension taking effect after September 2020, the duration spent in moratorium shall be examined in terms of loan loss provisioning, and the preferential treatment defined by the EBA would not apply to exposures that have been in moratorium for more than nine months between March 2020 and June 2021. As a result, the transactions involved in the extension of the moratorium, which have been in moratorium for more than nine months in total, would need to be re-categorised to the Stage 2 category of loan loss. Our estimates show that the loan portfolio affected by the extension of the payment moratorium may call for loan loss provisions in the amount of up to HUF 200-300 billion in 2021. The MNB, however, informed the institutions in an executive circular ${ }^{11}$ that it is considered to be a good practice to re-categorise exposures as restructured and classify them to Stage 2 only if a deterioration in the client's financial data is observed or if no information is available on its financial position; consequently, the ultimate impact may be expected to be lower. The MNB is also supporting the strengthening of the resilience of the banking system and the maintenance of its lending capacity with a number of additional measures: it is temporarily not sanctioning non-compliance with the capital conservation buffer and Pillar II Guidance lifted the capital buffer requirement for systemically important institutions, and it has decided to postpone the annual review of the systematic risk buffer in 2020.

\footnotetext{
${ }^{10} \mathrm{https}$ ///www.mnb.hu/sajtoszoba/sajtokozlemenyek/2020-evi-sajtokozlemenyek/hitelbovules-biztonsagosmukodessel-jegybanki-utmutatas-a-bankoknak

${ }^{11} \mathrm{https}$ ://www.mnb.hu/letoltes/vezetoi-korlevel-az-ifrs-9-standard-alkalmazasaban-a-makrogazdasagiinformaciok-felhasznalasarol-es-a-hitelkockazat-jelentos-novekedeset-jelzo-tenyezokrol.pdf
} 


\section{Conclusions}

The payment moratorium introduced in Hungary as one of the first of its kind proved to be a widely used measure in an international comparison to address the liquidity difficulties caused by the coronavirus pandemic. The payment moratorium provides temporary relief for the repayment obligations of debtors, increases their disposable income and thus their savings, which can be used to offset the economic shocks caused by the pandemic. In addition to its widespread availability, the measure in Hungary was accompanied by a high level of participation, as about 60 per cent of the approximately 2.7 million retail bank clients, i.e. 1.6 million debtors, and roughly 50,000 businesses, half of all corporate debtors eligible for the moratorium entered the moratorium having at least one loan.

In our study, we reviewed the demographic, income and wealth characteristics of clients participating in the moratorium based on the uniquely detailed data available to the MNB. As a result, we found the shock resilience of clients entering the moratorium is lower than the ones opting out of the moratorium. In terms of income and labour market characteristics, there is a higher proportion of clients participating in the moratorium with a low level of education, part-time employees or job seekers, more indebted clients and clients with a low amount of savings. Based on the previously discussed findings, the existence of a moratorium has an adverse selection effect in itself, as those clients in need of a moratorium have a higher rate of using the programme than those who have adequate repayment capacity in spite of the effects of the pandemic. The tendency can also be observed in the case of corporate loans: companies more indebted or operating in sectors that are more exposed to the economic difficulties caused by the coronavirus have largely gathered under the protective shield of the moratorium.

At the level of the national economy, households and companies participating in the payment moratorium are estimated ${ }^{12}$ to receive about HUF 1,700 billion of excess liquidity by the end of 2020 due to the moratorium, which amounts to 3.5-3.7 per cent of 2019 GDP. Of this figure, the household segment accounts for about HUF 580-620 billion, or 1.2-1.3 per cent of 2019 GDP. The liquidity effect on households is mainly due to mortgage instalments amounting to HUF 300-310 billion and personal loan instalments amounting to HUF 160-170 billion, which is complemented by repayments on other, less common types of loans. In the corporate segment, the liquidity effect of the moratorium can be estimated at HUF 1,100 billion by the end of the year, i.e. 2.3-2.4 per cent of 2019 GDP. Similar effects are expected after the extension of the payment moratorium. According to our estimate, the six-month extension of the moratorium could leave about

${ }^{12}$ Calculated on the basis of the proportion of loans under moratorium in each month, and assuming no change from September in the proportions of August. 
HUF 420-460 billion in excess liquidity for households and HUF $680-740$ billion for companies. The payment moratorium has thus made it possible to implement a significant economic recovery measure at the level of the national economy. In addition, the payment moratorium provides more time for debtors to make the necessary adjustments, so it can be assumed that the potential credit loss to be realised after the moratorium may remain modest compared to the financial crisis in 2008.

However, the picture is nuanced by the fact that, in terms of the credit risk characteristics of clients entering and opting out of the moratorium, in addition to vulnerable debtors, a significant proportion of less vulnerable debtors also participated in the moratorium. On the one hand, a prolonged moratorium which goes beyond the pandemic will increase the interest accrued during the moratorium and be repaid later. On the other hand, it may obscure the real repayment capacity of clients, and a long-term suspension of repayment may even worsen their payment discipline in the future. The general nature of the moratorium may further increase moral hazard, which may reduce the repayment willingness of some debtors upon maintaining the measure in the long term. All of these factors may contribute to the fact that the portfolio of problematic bank loans may rise after the end of the moratorium, worsening the lending capacity of banks due to the incurred losses and thus increasing risks to financial stability. Over the longer term, these may be partially mitigated by proactive restructuring of loans and, in the case of consistently non-performing exposures, by sales to winding-up institutions.

On the creditors' side, the payment moratorium and the extension thereof may cause a limited and manageable direct loss of approximately HUF 35-45 billion until June 2021, due to the change in the present value of loans. The extension of the moratorium may also result in a need for loan loss provisioning of up to HUF 200-300 billion on the banks' side due to the relevant accounting rules. At the same time, the programme can partially mitigate potential losses of creditors by maintaining the portfolio quality and improving the overall business environment. Furthermore, the domestic banking system had enhanced resilience compared to the previous crisis, and was in an adequate capital and liquidity position when hit by the coronavirus pandemic, which helps to manage any losses that may arise. Overall, the benefits of the moratorium realised during the crisis may far outweigh its potential risks, and accordingly in our view, the measure has proven to be an effective and efficient crisis management tool. However, it is important to emphasise that the moratorium is a temporary tool to mitigate the effects of exogenous shocks to the economy. Prolonged solutions which go beyond the epidemic situation may lead to significant moral hazard and financial stability problems. 


\section{References}

Báger, G. - Parragh, B. (2020): A koronavírus-válság, fenntartható fejlödés és az ösztönző állam modellje (The Coronavirus Crisis, Sustainable Development and the Incentive State Model). Pénzügyi Szemle (Public Finance Quarterly), 65(Különszám): 86-113. https://doi. org/10.35551/PSZ_2020_k_2_4

BIS (2020a): Prudential response to debt under Covid-19: the supervisory challenges. FSI Briefs No. 10., Bank for International Settlements, August. https://www.bis.org/fsi/fsibriefs10.pdf

BIS (2020b): Buffering Covid-19 losses - the role of prudential policy. BIS Bulletin No. 9., Bank for International Settlements, April. https://www.bis.org/publ/bisbull09.pdf

BIS (2020c): Payment holidays in the age of Covid: implications for loan valuations, market trust and financial stability. FSI Briefs No 8, Financial Stability Institute, Bank for International Settlements. https://www.bis.org/fsi/fsibriefs8.pdf. Downloaded: 12 November 2020.

BIS (2021): Covid-19 and cyber risk in the financial sector. BIS Bulletin No. 37, Bank for International Settlements, January. https://www.bis.org/publ/bisbull37.pdf

Boldizsár, A. - Kékesi, Zs. - Kóczián, B. - Sisak, B. (2016): The Wealth Position of Hungarian Households based on HFCS. Financial and Economic Review, 15(4): 115-150. https://enhitelintezetiszemle.mnb.hu/letoltes/anna-boldizsar-zsuzsa-kekesi-balazs-koczian-balazssisak.pdf

Collins, J.M. - Urban, C. (2018): The effects of a foreclosure moratorium on loan repayment behaviors. Regional Science and Urban Economics, 68(January): 73-83. https://doi. org/10.1016/j.regsciurbeco.2017.10.010

Duignan, D. - McGeever, N. (2020): Which firms took COVID-19 payment breaks? Financial Stability Notes 2020/6, Central Bank of Ireland. https://www.centralbank.ie/docs/defaultsource/publications/financial-stability-notes/no-6-which-firms-took-covid-19-paymentbreaks-(duignan-and-mcgeever).pdf

EBA (2020a): Risk assessment of the European banking system. European Banking Authority, December. https://www.eba.europa.eu/sites/default/documents/files/document_library/ Risk\%20Analysis\%20and\%20Data/Risk\%20Assessment\%20Reports/2020/December\%20 2020/961060/Risk\%20Assessment_Report_December_2020.pdf

EBA (2020b): Guidelines on legislative and non-legislative moratoria on loan repayments applied in the light of the COVID-19 crisis. European Banking Authority. https://eba.europa. eu/regulation-and-policy/credit-risk/guidelines-legislative-and-non-legislative-moratorialoan-repayments-applied-light-covid-19-crisis. Downloaded: 5 January 2021. 
FSB (2020): COVID-19 Pandemic: Financial Stability Implications and Policy Measures Taken. Financial Stability Board. https://www.fsb.org/wp-content/uploads/P150720-2.pdf. Downloaded: 8 February 2021.

Gaffney, E. - Greaney, D. (2020): COVID-19 payment breaks on residential mortgages, Financial Stability Note 2020/5, Central Bank of Ireland. https://www.centralbank.ie/docs/ default-source/publications/financial-stability-notes/no-5-covid-19-payment-breaks-onresidential-mortgages-(gaffney-and-greaney).pdf?sfvrsn=4

IMF (2020): Global Financial Stability Report: Bridge to recovery. International Monetary Fund. http://dx.doi.org/10.5089/9781513554228.082

IMF (2021): Global Financial Stability Report Update, January 2021: Vaccines Inoculate Markets, but Policy Support Is Still Needed, International Monetary Fund. https://www. imf.org/-/media/Files/Publications/GFSR/2021/January/English/text.ashx. Downloaded: 8 February 2021.

MNB (2020a): Macroprudential Report - 2020. Magyar Nemzeti Bank. https://www.mnb. hu/letoltes/macroprudential-report-2020.pdf

MNB (2020b): Financial Stability Report - May 2020. Magyar Nemzeti Bank. https://www. $\mathrm{mnb}$.hu/letoltes/financial-stability-report-2020-may.pdf

MNB (2020c): Financial Stability Report - November 2020. Magyar Nemzeti Bank. https:// www.mnb.hu/letoltes/financial-stability-report-2020-november.pdf

Terták, E. - Kovács, L. (2020): A szociális védelem és a társadalmi kohézió kihívásai válsághelyzetben a pénzügyi szférában (Challenges to Social Protection and Social Cohesion in Crises in the Financial Sector). Pénzügyi Szemle (Public Finance Quarterly), 65(3): 364384. https://doi.org/10.35551/PSZ_2020_3_3 